PNNL-11121

UC-810

Project Technical Information

\title{
Assessment of Commercially Available Ion Exchange Materials for Cesium Removal from Highly Alkaline Wastes
}

K. P. Brooks

A. Y. Kim

D. E. Kurath

April 1996

Prepared for

the U.S. Department of Energy under Contract DE-AC06-76RLO 1830

Pacific Northwest National Laboratory

Richland, Washington 99352

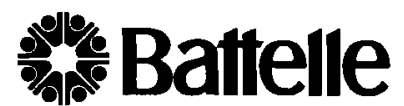


PNNL-11121

UC-810

\title{
Assessment of Commercially Available Ion Exchange Materials for Cesium Removal from Highly Alkaline Wastes
}

\author{
KP Brooks \\ AY Kim \\ DE Kurath
}

April 1996

Prepared for

the U.S. Department of Energy

under Contract DE-AC06-76RLO 1830

Pacific Northwest National Laboratory

Richland, Washington 99352

Reprint of historical document TWRSPP-94-095, dated September 1994. Data, formatting, and other conventions reflect standards at the original date of printing. Technical peer reviews and editorial reviews may not have been performed 


\title{
DISCLAIMER
}

This report was prepared as an account of work sponsored by an agency of the United States Government. Neither the United States Government nor any agency thereof, nor Battelle Memorial Institute, nor any of their employees, makes any warranty, express or implied, or assumes any legal liability or responsibility for the accuracy, completeness, or, usefulness of any information, apparatus, product, or process disclosed, or represents that its use would not infringe privately owned rights. Reference herein to any specific commercial product, process, or service by trade name, trademark, manufacturer, or othenvise does not necessarily constitute or imply its endorsement, recommendation, or favoring by the United States Government or any agency thereof, or Battelle Memorial Institute. The views and opinions of authors expressed herein do not necessarily state or reflect those of the United States Government or any agency thereof.

\author{
PACIFIC NORTHWEST NATIONAL LABORATORY \\ operated by \\ BATTELLE \\ for the \\ UNITED STATES DEPARTMENT OF ENERGY \\ under Contract DE-AC06-76RLO 1830
}

\author{
Printed in the United States of America \\ Available to DOE and DOE contractors from the \\ Orice of Scientivir and Tecinniral Information. P.O. Box 62, Oak Ridge, TN 37831; \\ prices available from (615) 576-8401.
}

Available to the public from the National Technical Information Service, U.S. Department of Commerce, 5285 Port Royal Rd., Springfield, VA 22161 


\section{SUMMARY}

Ion exchange is the leading candidate process for radioactive cesium removal from Hanford's alkaline supernates and dissolved salt cakes. Duolite ${ }^{\mathrm{TM}}$ CS-100 has been chosen as the baseline material for cesium ion exchange in the Initial Pretreatment Module (IPM) conceptual design. A final exchanger down-selection will occur in FY 96 before IPM Title I design. At that time, other cesium exchange materials will be considered to replace CS- 100 . This report presents the results of an evaluation of commercially available exchangers to determine which materials warrant further investigation. Only exchangers which are currently in production or which can be purchased by special order have been included in this study.

To identify candidate exchangers, representatives from major ion exchange manufacturers were consulted and literature from the DOE complex was reviewed. The exchangers which were evaluated are shown in Table S.1. These materials were compared based on the following criteria: (1) cesium distribution coefficient, (2) rate of cesium sorption, (3) elution characteristics, and (4) chemical and radiochemical stability. Each exchanger was compared to the baseline CS-100 resin. Resins with cesium distribution coefficients markedly lower than CS-100 were eliminated from consideration.

TABLE S1. List of Ion Exchange Materials Studied

\begin{tabular}{|c|c|c|}
\hline Organic Resins & Organic Resins & Inorganic Zeolites \\
\hline Duolite $^{\mathrm{TM}}$ CS-100 & Amberlite $^{\mathrm{TM}}$ IRC-718 & Durasil 210 \\
\hline Resorcinol Formaldehyde & Amberlite $^{\mathrm{TM}}$ IRC-50 & Durasil $^{\bullet} 230$ \\
\hline Duolite $^{\mathrm{TM}} \mathrm{C}-3$ & Amberlite $^{\mathrm{TM}}$ DP-1 & Ionsiv $^{\mathrm{TM}}$ IE-95 \\
\hline Lewatit $^{\mathrm{TM}}$ TP-207 & ResinTech SIR-300 & Ionsiv $^{\mathrm{TM}}$ IE-96 \\
\hline
\end{tabular}

Very few ion exchange materials show strong cesium selectivity in highly alkaline solutions. Of the eight organic resins studied, only resorcinol-formaldehyde (R-F) and Duolite C-3 resins have distribution coefficients as high or higher than CS-100. All of the zeolite materials were also found to have cesium distribution coefficients of similar magnitude to CS- 
100. A summary of how these materials compare in terms of the selection criteria is shown in Table S.2.

Although R-F resin has a significantly higher distribution coefficient than CS-100, the elutability and chemical and radiochemical stability of the resin may be a concern. Duolite ${ }^{\mathrm{TM}} \mathrm{C}$ 3 has equilibrium behavior similar to CS-100, but information is lacking with regards to mass transfer rate and chemical stability. Furthermore, in the one elution test performed, C-3 showed poor elutability.

Zeolites have similar cesium sorption characteristics to CS-100. However, their poor chemical stability in both high caustic and acidic make loading in Hanford wastes and subsequent elution difficult. Furthermore, since no eluants for zeolites are now being considered, the loaded exchanger would be vitrified as high level waste. Studies have shown that excessive amounts of HLW glass would be produced if zeolites were used.

TABLE S2. Summary of Exchanger Properties Relative to CS-100

\begin{tabular}{|l|c|c|c|c|}
\hline Property & CS-100 & R-F & C-3 & Zeolites \\
\hline $\begin{array}{l}\text { Distribution } \\
\text { Coefficient }\end{array}$ & average & very high & average & average \\
\hline $\begin{array}{l}\text { Mass Transfer } \\
\text { Rate }\end{array}$ & high & high & - & average \\
\hline Elutability & high & average & low & very low \\
\hline $\begin{array}{l}\text { Chemical } \\
\text { Stability }\end{array}$ & average & below average & - & low \\
\hline $\begin{array}{l}\text { Radiation } \\
\text { Stability }\end{array}$ & average & below average & average & very high \\
\hline \hline
\end{tabular}

Future research should focus on addressing the limitations of these exchangers. The chemical and radiochemical stability of R-F resin should be verified with further testing using the newly available BSC-210 batch of R-F resin. The resin's stability should be studied in the context of the full-scale ion exchange process to determine how significant these problems really are. 
Duolite C-3 was originally eliminated from consideration because it had to be purchased by special order. Now that all organic resins require special order purchase, use of this resin should be considered as a viable alternative to CS-100. Future work should obtain the data required to compare C-3 to CS-100. 


\section{ACKNOWLEDGEMENT}

The authors would like to thank. S. Fredric Marsh of Sandia National Laboratories and Zita V. Svitra of Los Alamos National Laboratory for obtaining the batch distribution coefficients for the ion exchange materials and advising the authors on ion exchange material characteristics. 


\section{CONTENTS}

SUMMARY

iii

ACKNOWLEDGEMENT $\ldots \ldots \ldots \ldots \ldots \ldots \ldots \ldots \ldots \ldots \ldots \ldots \ldots \ldots \ldots$

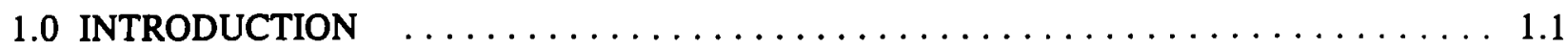

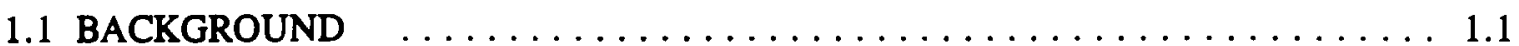

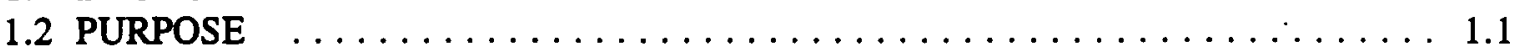

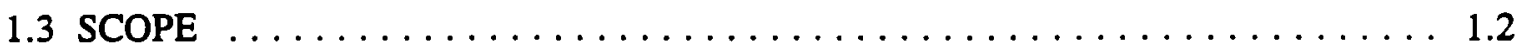

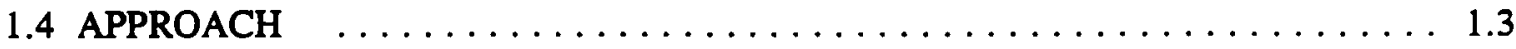

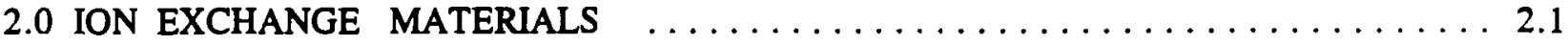

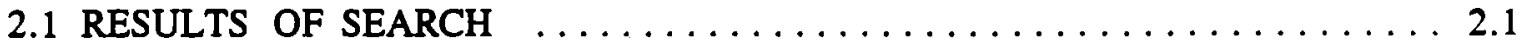

2.2 ION EXCHANGER PROPERTIES AND HISTORY $\ldots \ldots \ldots \ldots \ldots \ldots \ldots 2.2$

3.0 EVALUATION OF ION EXCHANGE MATERIALS $\ldots \ldots \ldots \ldots \ldots \ldots \ldots \ldots \ldots .1$

3.1 COMPARISON OF DISTRIBUTION COEFFICIENT $\ldots \ldots \ldots \ldots \ldots \ldots \ldots 3.1$

3.2 COMPARISON OF MASS TRANSFER RATES $\ldots \ldots \ldots \ldots \ldots \ldots \ldots \ldots .4$

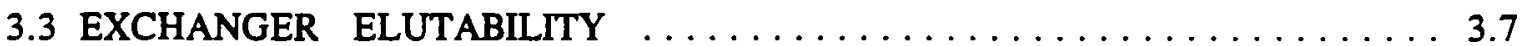

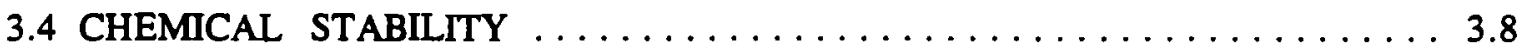

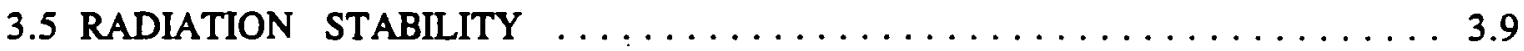

4.0 CONCLUSIONS AND RECOMMENDATIONS $\ldots \ldots \ldots \ldots \ldots \ldots \ldots \ldots \ldots$

5.0 REFERENCES $\ldots \ldots \ldots \ldots \ldots \ldots \ldots \ldots \ldots \ldots \ldots \ldots \ldots \ldots \ldots \ldots \ldots$

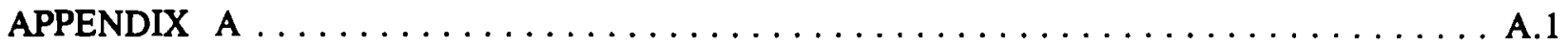

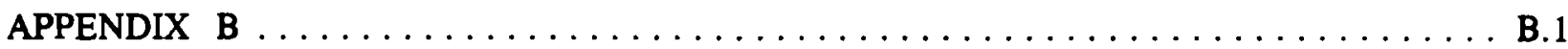




\section{FIGURES}

3.1 Cesium Batch $\mathrm{Kd}$ for CS-100 and R-F as a Function of Gamma Dose. Kd Taken with NCAW for CS-100 and a $6 \underline{\mathrm{M} \mathrm{Na}}{ }^{+}, 1.5 \underline{\mathrm{M}} \mathrm{OH}, 2 \times 10^{-4} \underline{\mathrm{M}}$ Cs Solution for R-F

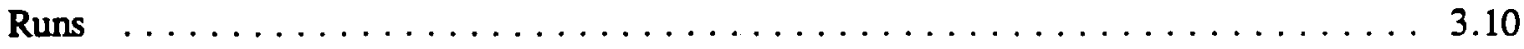




\section{TABLES}

S1 List of Ion Exchange Materials Studied $\ldots \ldots \ldots \ldots \ldots \ldots \ldots \ldots \ldots$ iii

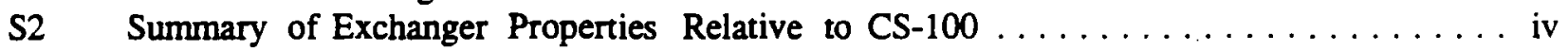

1.1 Simulated Hanford Alkaline Waste Solutions $\ldots \ldots \ldots \ldots \ldots \ldots \ldots \ldots \ldots$

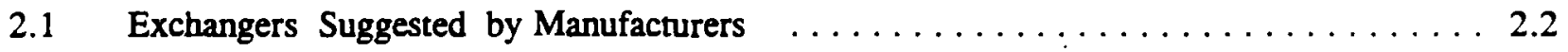

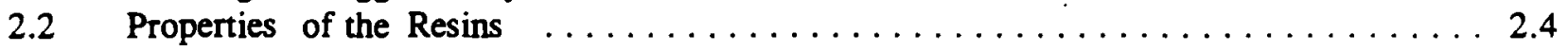

3.1 Batch Distribution Coefficients for Resins Studied $\ldots \ldots \ldots \ldots \ldots \ldots \ldots \ldots$

3.2 Particle-Phase Diffusivities and Number of Transfer Units from Batch Tests . . . . 3.6

3:3 Particle-Phase Diffusivities and Number of Transfer Units from Column Tests . . . . 3.7

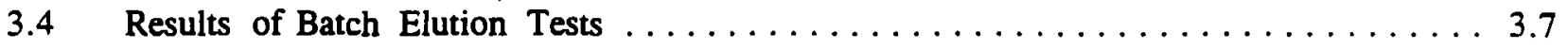




\subsection{INTRODUCTION}

\subsection{BACKGROUND}

Approximately 61 million gallons of nuclear waste generated in plutonium production, radionuclide removal campaigns, and research and development activities is stored on the Department of Energy's Hanford Site, near Richland, Washington. The waste is stored in 177 underground storage tanks (USTs) as a mixture of sludge, salt cake, and alkaline supernatant. The sludge fraction of the waste consists of metal oxides and hydroxides and contains most of the radionuclides of concern (e.g. Sr, $\mathrm{Pu}, \mathrm{Am}, \mathrm{U}$ ). The salt cake consists primarily of dried sodium salts, and the supernates are concentrated aqueous solutions of sodium salts. Radioactive cesium $\left({ }^{137} \mathrm{Cs}\right)$ is the primary water soluble radionuclide contained in the salt cake and supernatant solutions.

The disposal options for these wastes are either as high-level waste (HLW) glass for disposal in a repository or as low-level waste (LLW) glass for on-site disposal. To reduce disposal costs and comply with environmental regulations, waste pretreatment will separate the small quantities of radionuclides from the bulk non-radioactive chemicals. Although the pretreatment process and disposal requirements are still being defined, most pretreatment scenarios include removal of cesium from the aqueous streams. In many cases, after cesium is removed, the dissolved salt cakes and supernates can be disposed of as LLW. Ion exchange has been a leading candidate for this separation. Ion exchange systems have the advantage of simplicity of equipment and operation and provide many theoretical stages in a small space.

\subsection{PURPOSE}

The organic ion exchange material Duolite ${ }^{\mathrm{TM}}$ CS-100 has been selected as the baseline exchanger for conceptual design of the Initial Pretreatment Module (IPM) by the Westinghouse Hanford Company (WHC). Use of CS-100 was chosen because it is considered a conservative, technologically feasible approach. During FY 96, final resin down-selection will occur for IPM Title I design. Alternate ion exchange materials for cesium exchange will be considered at that time.

The purpose of this report is to conduct a search for commercially available ion exchange materials which could potentially replace CS-100. This report will provide where 
possible a comparison of these resin in their ability to remove low concentrations of cesium from highly alkaline solutions. Materials which show promise can be studied further, while less encouraging resins can be eliminated from consideration.

\section{$1.3 \underline{\text { SCOPE }}$}

This assessment will include only ion exchange materials which are currently in production or which are available by special order. Ion exchange materials which have been used in the past, but which are now not commercially available will be mentioned, but not included. There are several cesium selective resins which are now under development by EM-50 which are not commercially available. These materials are not considered in this report.

The supernate from the USTs varies widely in composition. For the purpose of this study, these exchangers were evaluated with Neutralized Current Acid Waste (NCAW), Double Shell Slurry Feed (DSSF), and West Valley Alkaline Supernate (WVAS) simulants. The compositions of the waste simulants are shown in Table 1.1. The NCAW simulant was modeled after the composition of Hanford tank 241-AZ-101 and represents a high sodium and cesium waste. The DSSF simulant was modeled after the composition of Hanford tank 241-AW-101 and represents a high sodium and potassium and low cesium waste (Kurath et al. 1994). The WVAS simulant is similar to NCAW in composition and was modeled after West Valley highlevel waste tank 8D2 (Bray et al. 1984).

TABLE 1.1. Simulated Hanford Alkaline Waste Solutions

\begin{tabular}{|c|c|c|c|}
\hline Species, Total & NCAW, M & DSSF-7, M & WVAS, M \\
\hline $\mathrm{Na}$ & 4.987 & 7.000 & 8.7 \\
\hline K & 0.120 & 0.945 & 0.01 \\
\hline $\mathbf{R b}$ & $5.0 \mathrm{E}-05$ & - & - \\
\hline Cs & $5.0 \mathrm{E}-04$ & $7.0 \mathrm{E}-05$ & $7.8 \mathrm{E}-04$ \\
\hline $\mathrm{Al}$ & 0.430 & 0.721 & - \\
\hline $\mathrm{SO}_{4}$ & 0.150 & 0.008 & 0.29 \\
\hline $\mathrm{OH}$ (Total) & 3.400 & 4.634 & - \\
\hline OH (Free) & 1.680 & 1.750 & $\mathrm{pH}=10$ \\
\hline $\mathrm{CO}_{3}$. & 0.230 & 0.147 & 0.5 \\
\hline $\mathrm{NO}_{2}$ & 0.430 & 1.512 & 1.6 \\
\hline $\mathrm{NO}_{3}$ & 1.669 & 3.521 & 3.1 \\
\hline$F^{3}$ & 0.089 & - & \\
\hline $\mathrm{Cl}$ & - & 0.120 & 0.004 \\
\hline $\mathrm{PO}_{4}$ & 0.025 & 0.014 & 0.06 \\
\hline
\end{tabular}




\subsection{APPROACH}

Two approaches were taken to identify candidate materials which might be selective for cesium. First, technical and sales representatives from major manufacturers of ion exchangers were contacted and asked to suggest ion exchange materials which they considered as potentially selective for cesium in highly alkaline solutions. Samples of these materials were sent to Los Alamos National Laboratory (LANL) for determination of the batch distribution coefficient with NCAW and DSSF. Second, data was collected from past studies by PNL, WHC, and others which provided assessments of ion exchange materials. Only commercially available ion exchange materials identified in the literature search were included in this study.

The exchangers were compared in four categories: (1) cesium batch distribution coefficient, (2) rate of cesium sorption, (3) elution characteristics, and (4) chemical and radiochemical stability. The exchange materials were compared with the baseline CS-100 to facilitate the comparison. Exchangers which exhibited poor cesium distribution coefficients were eliminated from further study. Exchangers which had similar or higher cesium batch distribution coefficients than CS-100 were studied further in terms of the subsequent three categories where data was available. 


\subsection{ION EXCHANGE MATERIALS}

This section provides a description of the ion exchange materials studied in this report. It delineates how the materials were identified and their properties.

\subsection{RESULTS OF SEARCH}

Table 2.1 presents the resins suggested by the manufacturer representatives. In many cases, the company did not have an exchanger which they believed was selective for cesium in highly alkaline solutions. In other cases, the company did not have materials available which were known to be selective cesium in alkaline solutions. When resins were suggested for these cases, their cesium selectivity was not known but the company representative believed that they could provide some cesium selectivity. These resins are indicated with a (U) in the table below. The resins known to be selective for cesium, at least to some extent are indicated with a (K).

A review of past literature was undertaken to find cesium selective exchangers. A variety of materials were found in these past reports. Bray, et al (1984) studied Duolite CS-100, Ionsiv IE-95, Duolite ARC-359 ${ }^{1}$, and Amberlite IRC-718 exchangers with West Valley Alkaline supernatant. Gallagher (1986) provided sorption and column data on CS-100, Zeolon 900, Duolite ARC-9359, and Durasil 210 contacted with NCAW simulant. The memos from Prignano (1989a and b) provided batch distribution information in NCAW and $\mathrm{HNO}_{3}$ elution with Duolite CS-100, resorcinol formaldehyde (R-F), Duolite C-3, and ARC-359N in NCAW simulant. More recent work has focused on cesium sorption with IE-96, R-F, and CS-100 resins (Bray, et al. 1992; Kurath et al 1994). Marsh, et al. (1994a) has recently completed a comparison of resins in 101-SY simulant with CS-100, R-F, Ionsiv TIE-96 (IE-96 with titanium to improve Pu and Sr sorption), Durasil 230, and several other exchangers. In an electrochemical system developed in the UK, Lewatit DN-KR and R-F resins were tested for cesium removal from a NCAW simulant (Griffiths 1994).

Duolite ARC-359, -9359 , and $-359 \mathrm{~N}$ are all believed to be analytical grades of Duolite C3. Rohm and Haas does not currently manufacture these analytical grade resins. 
TABLE 2.1. Exchangers Suggested by Manufacturers

\begin{tabular}{||l|c|c||}
\hline Resin Manufacture & Name of Contact & Suggested Resins \\
\hline Rohm and Haas & Lloyd Brown & $\begin{array}{c}\text { Amberlite IRC-718 (U) } \\
\text { Amberlite DP-1 (U) } \\
\text { Amberlite IRC-76 (U) }\end{array}$ \\
\hline Resin Tech & Douglas Kellogg & RT-3972 (U) \\
\hline Miles & Italious Chiari & Lewatit TP-207 (U) \\
\hline UOP & Dennis Fennelly & $\begin{array}{c}\text { Ionsiv IE-95 (K) } \\
\text { Ionsiv IE-96 (K) }\end{array}$ \\
\hline GTS Duratek & Regina Mowad & $\begin{array}{c}\text { Durasil 190 (K) } \\
\text { Durasil 230 (K) }\end{array}$ \\
\hline Vydac & Yanbo Yang & Nothing selective for Cs \\
\hline Pharmacia & Randy Lowe & Nothing selective for Cs \\
\hline Purolite & Jim DeBenedictis & Nothing selective for Cs \\
\hline Sybron & Dave Dally & Nothing as selective as CS-100 \\
\hline Dow Chemical & Phyllis Ferris & Nothing as selective as CS-100 \\
\hline
\end{tabular}

\subsection{ION EXCHANGER PROPERTIES AND HISTORY}

Table 2.2 displays the properties of the ion exchangers studied here. Note that the list contains a variety of functionalities, purposes, and costs. The phenolic resins have been used successfully for cesium ion exchange, while other exchangers have not. The phenolics are granular in structure while the other exchangers are spherical and usually macroreticular (macroporous); the phenolic materials are made by a process which cannot produce spherical, macroporous beads. Furthermore, the commercially available phenolic resins (CS-100, R-F, and C-3) are not stock items and must be produced on a special order basis.

Most exchangers which were studied in the literanure but are not commercially available have been eliminated from this list. Zeolon $900^{2}$ and Duolite ARC- $359^{3}$ are two of the

2 Zeolon 900 was originally produced by Norton Co. Worchester, MA. Philadelphia Quartz now owns the rights to its production, but does not produce this material. It produces similar but not identical mortenite materials: CBV10A-X16 and CP461. 
exchangers which will not be studied here. Although Lewatit DN-KR ${ }^{4}$ and Durasil 210 are not currently commercially available, because batch distributions for these exchangers were recently performed and it showed reasonable selectivity for cesium, they have been included in the evaluation.

The Rohm and Haas Duolite CS-100 resin has been used for several years as a full scale process to remove ${ }^{137} \mathrm{Cs}$ from alkaline low-level radioactive wastes at Oak Ridge National Laboratory (Chilton 1981). CS-100 was also considered for Hanford's B-plant for cesium removal from NCAW and CC wastes, but the process was never constructed. Currently, CS-100 is the IPM baseline for cesium ion exchange. Rohm and Haas will produce this resin on a special order basis only.

3 This exchanger was originally produced by Diamond Shamrock, but when the ion exchange products were sold to Rohm and Haas, this product was discontinued.

4 Originally produced by Miles, Inc. this material had a batch distribution coefficient similar to CS-100. However, this resin's manufacture has been discontinued both in the US and Germany for approximately 5 years. 


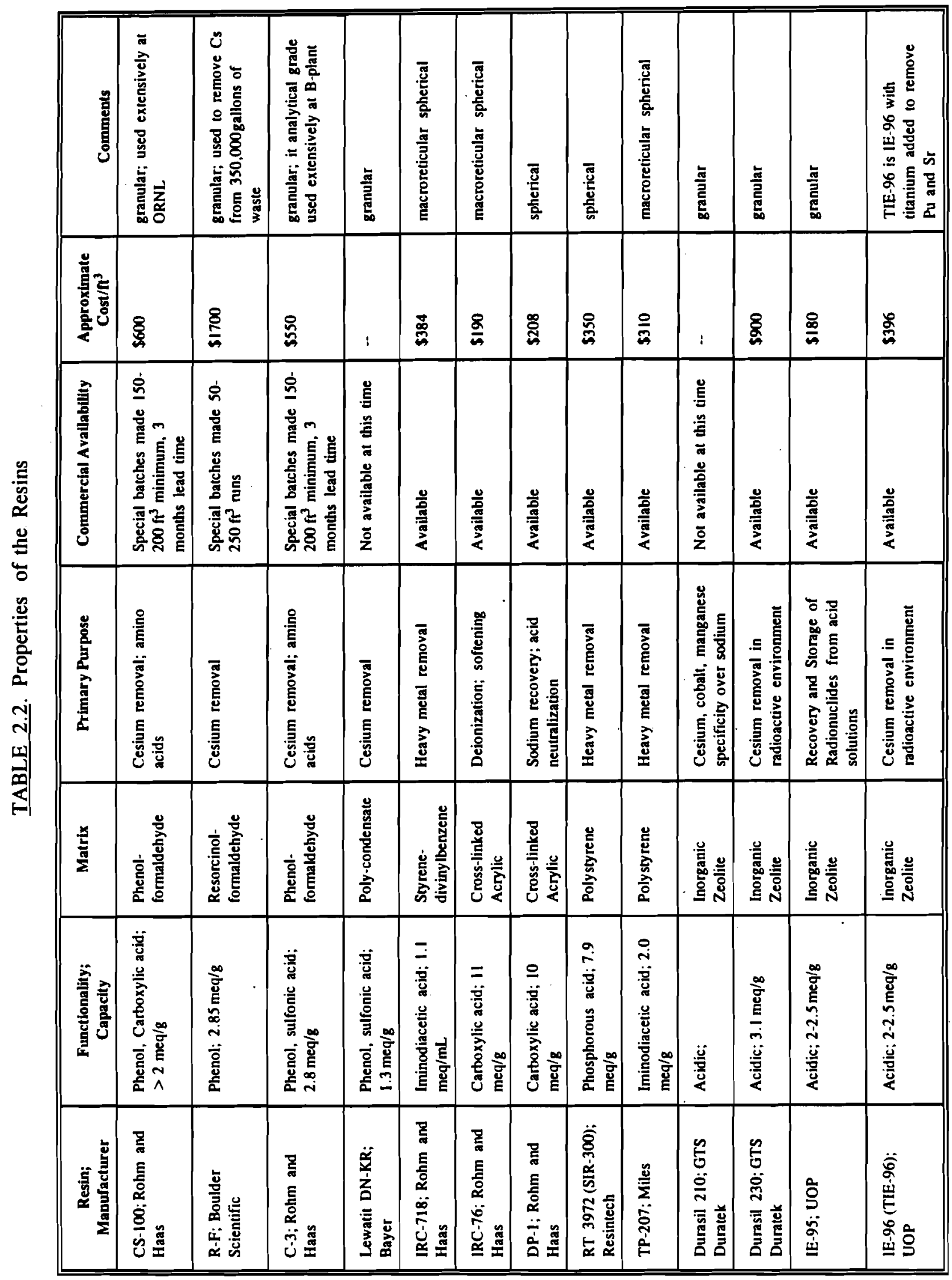


The resorcinol formaldehyde resin was first developed by Savannah River Laboratory in the early 1980s. It has been produced on a semi-commercial scale for the last six years by Boulder Scientific Company on a special order basis. This resin has been used once one a large scale to remove 700 curies of cesium from 350,000 gallons of alkaline waste $(\mathrm{pH}=11-12$ ). This was an experimental test done by ECOTECH at a General Electric power plant. ${ }^{5}$

The Rohm and Haas Duolite C-3 resin has been used in its analytical form (ARC-359) at Hanford's B-plant to remove cesium from highly alkaline wastes. It was also considered for use in the more recent B-plant operations. However, because it had to be purchased on a special order basis only, it was eliminated from consideration. It appears to be similar in composition to Lewatit DN KR, which is no longer available. Duolite C-3 continues to be made by Rohm and Haas on a special order basis.

Zeolites have been used extensively in a variety of nuclear applications for the removal of cesium. They have higher temperature and radiation stability than organic exchangers. Furthermore, the once-through processing usually done with zeolites offers operational simplicity since the exchanger can be disposed of fully loaded with cesium. Their general limitations are their chemical instability in highly alkaline solutions and their impact of the volume of final waste form when used on a once-through basis. UOP's zeolite exchangers Ionsiv IE-95 and IE96 have been studied extensively for cesium removal from alkaline wastes and TIE-96 are being used in the full-scale unit to remove cesium from the wastes at West Valley. Durasil 230 has also been used commercially for cesium removal from deionized waters to decontaminate streams containing $10^{-3} \mu \mathrm{Ci} / \mathrm{mL}$ of cesium.

5 Information is based on a discussion with John Birmingham, president of Boulder Scientific Company. 


\subsection{EVALUATION OF ION EXCHANGE MATERIALS}

Ion order for the exchangers discussed above to be considered for cesium ion exchange at Hanford, certain criteria were developed. The exchangers were evaluated based on their distribution coefficient (Section 3.1), mass transfer rate (Section 3.2), elutability (Section 3.3), and chemical (Section 3.4) and radiochemical stability (Section 3.5).

\subsection{COMPARISON OF DISTRIBUTION COEFFICIENT}

The Hanford alkaline wastes have high concentrations of sodium and potassium, as well as other multivalent cations. In order to be effective, the exchanger must be capable of separating the cesium from these other competing cations. The ion exchange process must create a cesium depleted stream for LLW disposal and produce a cesium concentrate streain which does not impact the volume of HLW glass requiring disposal. If it cannot provide this degree of separation, there is no value added by the ion exchange process.

The distribution coefficient $K_{d}$ is a measure of the effectiveness of a material to remove cesium from a liquid stream. It is defined as the ratio of cesium concentration in the solid to cesium concentration in the liquid. The $K_{d}$ is generally determined with batch contacts between the exchanger and solution and is calculated according to the following formula:

$$
K_{d}=\frac{\left(C_{i}-C_{f}\right)}{C_{i}} \frac{V_{s}}{m_{\theta}}
$$

where $C_{i}$ is the initial (before contact) and $C_{f}$ is the final concentration of cesium in solution, $m_{e}$ is the mass of exchanger used, and $V_{s}$ is the volume of solution. The distribution coefficient is specific to the temperature and concentration of other ions in solution.

A common basis was sought in which to compare the ion exchange resins. Solution concentration, volume, temperature, and dilution as well as the water content of the resin all affect the distribution coefficient obtained. Fortunately, CS-100 resin has been included in all batch distribution coefficient studies conducted. Therefore, not only is it the baseline for Hanford ion exchange, it will also be used here as a common basis of comparison. 
The distribution coefficients for the exchangers are presented for DSSF, NCAW, and WVAS simulant in Table 3.1. Based on the results of the table, only R-F resin consistently has a higher $K_{d}$ than CS-100. Duolite C-3 is the only other organic exchanger that has a high distribution coefficient.

The ion exchange resins suggested by manufacturers had distribution coefficients which were significantly less than CS-100 using NCAW, DSSF, and WVAS. Based on these results, they would be unacceptable for cesium ion exchange. On further inspection, most of these exchangers are primarily used for chelating multivalent ions. Since cesium is a univalent cation, it does not form chelates. Therefore it is not surprising that these exchangers produced unacceptable behavior. 
TABLE 3.1. Batch Distribution Coefficients for Resins Studied

\begin{tabular}{|c|c|c|c|c|c|c|c|}
\hline & \multicolumn{4}{|c|}{ NCAW } & \multicolumn{2}{|c|}{ DSSF } & \multirow{2}{*}{$\frac{\text { WVAS }}{\text { Bray }^{7}}$} \\
\hline & Marsh $^{1}$ & Prignano $^{2}$ & Gallagher $^{3}$ & Bray $^{4}$ & $\operatorname{Marsh}^{5}$ & Bray $^{6}$ & \\
\hline CS -100 & 96 & 120 & 30 & 45 & 50 & 70 & 14 \\
\hline$R-F$ & 666 & 1200 & - & 450 & 236 & 650 & - \\
\hline $\mathrm{C}-3$ & - & 115 & 35 & - & - & - & 12 \\
\hline IRC-718 & 0.1 & - & - & - & 2.0 & - & 2 \\
\hline IRC-76 & 0.8 & - & - & - & 4.2 & - & - \\
\hline DP-1 & 0.5 & - & - & - & 3.4 & - & $<1$ \\
\hline RT-3972 & 0.6 & - & - & - & 6.6 & - & - \\
\hline TP-207 & $<0.1$ & - & - & - & - & - & - \\
\hline $\begin{array}{l}\text { Durasil } \\
210 \\
\end{array}$ & - & - & 16 & - & - & - & - \\
\hline $\begin{array}{l}\text { Durasil } \\
230\end{array}$ & - & - & - & - & 13 & - & - \\
\hline IE-95 & - & - & - & - & - & - & 39 \\
\hline (T)IE-96 & 45 & - & - & 42 & 12 & - & - \\
\hline
\end{tabular}

1. Initial $\left[\mathrm{Cs}^{+}\right]=5 \times 10^{-4},\left[\mathrm{Na}^{+}\right]=5.0$, as received resin, ambient temperature. $\mathrm{K}_{\mathrm{d}}$ values obtained after only 6 hours of contact. The slower sorbing exchangers may not have reached equilibrium.

2. Initial $\left[\mathrm{Cs}^{+}\right]=2.4 \times 10^{-4},\left[\mathrm{Na}^{+}\right]=1.8$, as received resin, irradiated to $10^{7}$ rads. Slightly different NCAW simulant recipe than shown in Table 1.1.

3. Initial $\left[\mathrm{Cs}^{+}\right]=7.37 \times 10^{-4},\left[\mathrm{Na}^{+}\right]=1.94$, as received resin. Slightly different NCAW simulant recipe than shown in Table 1.1.

4. Final $\left[\mathrm{Cs}^{+}\right]=5 \times 10^{-4},\left[\mathrm{Na}^{+}\right]=5.0$, dried at $85 \mathrm{C}$, experimental run at $25 \mathrm{C}$.

5. Initial $\left[\mathrm{Cs}^{+}\right]=7 \times 10^{-5},\left[\mathrm{Na}^{+}\right]=7.0$, as received resin, ambient temperature. $\mathrm{K}_{d}$ values obtained after only 6 hours of contact. The slower sorbing exchangers may not have reached equilibrium.

6. Final $[\mathrm{Cs}+]=7 \times 10^{-5},\left[\mathrm{Na}^{+}\right]=7.0$, dried at $85 \mathrm{C}$, experiment run at $25 \mathrm{C}$.

7. Initial $\left[\mathrm{Cs}^{+}\right]=7.4 \times 10^{-4},\left[\mathrm{Na}^{+}\right]=8.7$, dried at $105 \mathrm{C}$, experimental run at ambient temperatures. These runs were performed at $\mathrm{pH}=10$ and 13. At $\mathrm{pH}=13$, IE-95 and CS-100 both have $\mathrm{K}_{\mathrm{d}}$ values of 34 . 
The inorganic ion exchange resins Durasil 210 and 230 and IE-95 and -96 in most cases had distribution coefficients of the same order of magnitude as CS-100. CS-100 in general had better selectivity than these zeolite materials. This result may be in part because zeolites have slower cesium sorption and the $K_{d}$ values for the Marsh data were allowed to equilibrate for only 6 hours. Thus the exchangers with slower kinetics have not reached equilibrium by the end of the test.

Batch distribution coefficients were measured with NCAW simulant and Lewatit DN-KR and R-F resins. Similar to the results of C-3 on Table 3.1, Lewatit DN-KR produced a $K_{d}$ value of $76 \mathrm{~mL} / \mathrm{g}$. R-F produced a $\mathrm{K}_{d}$ value of $458 \mathrm{~mL} / \mathrm{g}$. Because no additional data exists for Lewatit DN-KR and it is not commercially available, it will not be discussed further in this report.

The following materials have acceptable cesium selectivity for continued investigation in this report: CS-100, R-F, C-3, and the zeolite materials.

\subsection{COMPARISON OF MASS TRANSFER RATES}

The rate of ion exchange is important in the design and operation of the ion exchange system. The exchange rate will impact the size of the ion exchange columns required and/or the its flow rate. Similar to the $K_{d}$, kinetics is affected by the specific exchanger, solution concentration, and temperature at which the exchanger is operated.

The mass transfer rate for many of these ion exchange materials has been measured in one of two ways. In the work done by Marsh, et al (1994(a) and 1994(b)), the cesium uptake was measured at 30 minutes, 2 hours, and 6 hours. Using the cesium sorption at each of these time periods, the particle diffusivity can be approximated based on the formula:

$$
F=1-\frac{6}{\pi^{2}} \sum_{n=1}^{\infty} \frac{e^{\frac{-n^{2} \pi^{2} D t}{I^{2}}}}{n^{2}}
$$

where $\mathrm{F}$ is the fraction of equilibrium attained, $\mathrm{D}$ is the ion exchange particle diffusivity, and $\mathrm{r}$ is the particle radius. This formula assumes (1) particle diffusion is rate controlling, and (2) infinite solution volume (concentration in the solution is constant). Assumption (1) is based on 
the composition and extent of solution mixing and may or may not be true. Assumption (2) is not true under the conditions of study. Furthermore, Marsh only provides three data points to fit this equation. In cases where the mass transfer is very slow, the final distribution coefficient is not known. In order to determine the particle diffusivity, both the particle diffusivity and the final distribution coefficient are adjusted to minimize error between the model and the experimental values. Therefore, the diffusivities obtained from this approach may not be completely accurate. However, the results will provide a means of comparing the sorption rates of the resins.

A second method of determining the rate of mass transfer is through column breakthrough curves. Experimental breakthrough curves exist at a range of flow rates. A column ion exchange model was developed which regresses the mass transfer coefficient (Kurath et al. 1994). The particle diffusivity (assuming once again no film mass transfer resistance) can be calculated from the mass transfer coefficient based on the formula:

$$
k_{p} a=\frac{60 D}{d_{p}^{2}}
$$

where $k_{p} a$ is the mass transfer coefficient assuming particle diffusion limited mass transfer, $D$ is the particle diffusivity, and $d_{p}$ is the resin particle diameter. Both these methods will be employed to compare ion exchange resin kinetics.

The particle diffusivity describes the rate of diffusion of cesium into a particle but does not necessarily describe the performance of the ion exchange column. The number of transfer units $(\mathrm{N})$, provides a factor which is proportional to the slope of the ion exchange breakthrough curve (Perry and Chilton 1973):

$$
N=\frac{60 K_{d} \rho_{b} D v}{d_{p}^{2} F}
$$

where $\rho_{b}$ is the bed density, $v$ is the bed volume, $F$ is the volumetric flow rate, and $d_{p}$ is the particle diameter. Both the particle diffusivity (D) and the number of transfer units (N) will be presented to compare the exchanger kinetics. 
Using Marsh's data (1994b), the particle diffusivities and number of transfer units of CS100, R-F, TIE-96, and Durasil 230 were calculated. These are shown in Table 3.2. Based on the data, CS-100 has the fastest kinetics; nearly an order of magnitude higher than the other exchangers shown. This also results in a larger number of transfer units for CS-100. R-F resin has very slow kinetics, especially in the case of DSSF, but because of its high $\mathrm{K}_{d}$, it has a reasonable number of transfer units. Both the zeolites have similar diffusivities which fall between CS-100 and R-F resins. In the case of C-3 and the other zeolites, no mass transfer data is available.

TABLE 3.2. Particle-Phase Diffusivities and Number of Transfer Units from Batch Tests

\begin{tabular}{||l|c|c|c|c||}
\hline \multirow{2}{*}{ Exchanger } & \multicolumn{2}{|c|}{ NCAW } & \multicolumn{2}{c||}{ DSSF } \\
\cline { 2 - 5 } & $\begin{array}{c}\mathrm{D} \\
\left(\mathrm{cm}^{2} / \mathrm{min}\right)\end{array}$ & $\mathrm{N}^{*}$ & $\begin{array}{c}\mathrm{D} \\
\left(\mathrm{cm}^{2} / \mathrm{min}\right)\end{array}$ & $\mathrm{N}^{*}$ \\
\hline CS-100 & $7 \times 10^{-6}$ & 93 & $7 \times 10^{-6}$ & 48 \\
\hline R-F & $1 \times 10^{-7}$ & 40 & $4 \times 10^{-8}$ & 9.3 \\
\hline TIE-96 & $6 \times 10^{-7}$ & 21 & $1 \times 10^{-6}$ & 9.2 \\
\hline Durasil 230 & - & - & $1.5 \times 10^{-6}$ & 13 \\
\hline
\end{tabular}

Based on data from Marsh $1994 \mathrm{~b}$

*Assuming $3 \mathrm{cv} / \mathrm{hr}$ flow rate.

Using the mass transfer coefficients from analysis of column run data, Kurath et al (1994), similar values are obtained (See Table 3.3). Although the method of obtaining this data is significantly different from that taken with the Marsh data, the result are very similar for R-F. The particle phase diffusivities of CS-100, however are lower than those obtained from the Marsh data, causing in turn a reduction in the number of mass transfer units. In this case, although R-F resin has a significantly lower cesium particle diffusivity than the other exchangers, it has more mass transfer units because of it high distribution coefficient. Therefore, the slope of the breakthrough curve will be acceptable for the R-F resin. 
TABLE 3.3. Particle-Phase Diffusivities and Number of Transfer Units from Column Tests

\begin{tabular}{||c|c|c|c|c||}
\hline \multirow{2}{*}{ Exchanger } & \multicolumn{2}{|c|}{ NCAW } & \multicolumn{2}{c||}{ DSSF } \\
\cline { 2 - 5 } & $\begin{array}{c}\mathrm{D} \\
\left(\mathrm{cm}^{2} / \mathrm{min}\right)\end{array}$ & $\mathrm{N}^{*}$ & $\begin{array}{c}\mathrm{D} \\
\left(\mathrm{cm}^{2} / \mathrm{min}\right)\end{array}$ & $\mathrm{N}^{*}$ \\
\hline CS-100 & $1 \times 10^{-6}$ & 12 & $1 \times 10^{-6}$ & 4.8 \\
\hline R-F & $2 \times 10^{-7}$ & 39 & $4 \times 10^{-8}$ & 5.8 \\
\hline
\end{tabular}

Based on data from Kurath 1994

Assuming $3 \mathrm{cv} / \mathrm{hr}$ flow rate.

\subsection{EXCHANGER ELUTABILITY}

Once exchange material in a column operation is loaded to equilibrium with cesium, either the cesium or the exchanger itself must be removed from the column and disposed of. In the case of organic exchangers, the cesium is most often eluted from the column using an acidic solution. A resin which cannot be eluted effectively may require an unrealistic quantity of eluant or may have to be removed from the column and disposed of after each loading cycle.

In the work done by Prignano (1989a), CS-100, C-3, and R-F were investigated for their elution characteristics using $0.3 \mathrm{M}$ nitric acid. The samples were allowed to equilibrate in a constant quantity of the eluant for four hours. The percent eluted from an average of three runs per resin is shown in Table 3.4. In this study, C-3 did not elute easily, while CS-100 eluted very nearly $100 \%$ of the cesium from the column. R-F resin eluted reasonably well.

TABLE 3.4. Results of Batch Elution Tests

\begin{tabular}{||l|c|}
\hline \multicolumn{1}{|c|}{ Exchanger } & Percent Eluted \\
\hline CS-100 & $100.1 \pm 3$ \\
\hline C-3 & $27.5 \pm 0.3$ \\
\hline R-F & $89 \pm 4$ \\
\hline
\end{tabular}

Data taken from Prignano (1989a)

In more recent studies, the elution of R-F resin was studied in a column arraignment (Kurath, et al. 1994). For these tests, it was difficult to remove the cesium down to a $C / C_{0}$ of 
less than 0.1 , even after passing 25 to 40 column volumes of acid through the column. The relatively poor elution behavior of the resin appears to be the result of resin agglomeration due to the $-35 \%$ volume shrinkage during elution. The shrinkage resulted in column channelling along the column walls. Recent runs with a newer batch of R-F (BSC-210) indicate much improved performance. Using BSC-210, the columns were eluted to a $C / C_{0}$ of of less than 0.01 in $11 \mathrm{cv}$. This is nearly the elution rates achieved with CS-100. The reason for this improved elution performance is still uncertain.

In general, zeolites have not eluted and are considered for once-through operation only. Because they are not reused after a loading cycle, other concerns must be addressed including: (1) their impact of the final waste form is more significant than eluted resins; and (2) the exchangers will be stored in the solid form, safety issues associated with their storage must be addressed:

Goheen and Kurath (1994) have shown that their use may be precluded due to the large increase in HLW glass logs produced as compared to an eluted exchanger. They found that in order to remove the cesium from a total blend of Hanford wastes using IE-96, 160,000 HLW canisters would be produced. For an eluted resin, only 26,000 HLW canisters would be produced in processing the same feed to similar cesium product levels.

\subsection{CHEMICAL STABILITY}

Study of the R-F resin has shown that its chemical stability during storage, loading, and cycling may be a concern. Ion exchange studies were performed with the R-F resin in 1988 . Similar experiments were performed with the same batch of resin in 1993 and the resin was shown to have degraded (Bibler 1994a). In some cases, the distribution coefficient decreased by more than an order of magnitude. The exact cause of the degradation was not clear. Freezing and oxidation were investigated but conclusions were not reached.

Resin degradation in caustic was studied with a $10 \underline{\mathrm{M} \mathrm{Na}}{ }^{+}$DSSF simulant by Bibler (1994b). The results of this study consistently show $>50 \%$ decrease in cesium distribution coefficient after the resin is exposed to the caustic solution for 451 hours.

The Bibler study contradicts the earlier work by Bray (1990). Using SRL simulant, Bray loaded and eluted the same ion exchange column for seven cycles. He found that the 
distribution coefficient decreased between the third and fifth cycle by approximately $20 \%$. The distribution coefficient remained relatively constant between the fifth and seventh cycle. Over the course of these cycles, the resin was exposed to caustic for approximately 700 hours, while in Bibler's work, the resin was exposed for only 451 hours. Therefore, the stability of R-F resin must be studied further to address this difference.

The results of Bray's work (1990) are very similar to those seen by Chilton (1981) with CS-100. Chilton cycled the resin between the acid and sodium form for 30 cycles. He found that the distribution coefficient of CS-100 decreased by approximately $2-3 \%$ after each cycle. Therefore, the resin degradation for both CS-100 and R-F during cycling appears to be fairly comparable.

Zeolites are not chemically compatible with highly alkaline wastes such as DSSF and NCAW and tend to degrade with time. Zeolites are contain significant quantities of aluminum. In high alkaline solutions, the caustic dissolves the aluminum as aluminate ion which in turn reduces the cesium $\mathrm{K}_{d}$ and/or capacity. Therefore, the hydroxide concentration must be considered before zeolites can be used. The operational range of Durasil 230, for example, is specified as between a $\mathrm{pH}$ of 3 and 10 .

\subsection{RADIATION STABILITY}

Zeolite materials, being inorganic, are virtually immune to radiation damage. Organic materials, however, degrade with accumulated radiation dose. Several static radiation studies have been performed to quantify its effect (Bibler et. al. 1990; Bibier 1994b; Bryan 1993). These results are shown in Figure 3.1. Bibler's work measured the distribution coefficient of R-F resin. For both cases, the distribution coefficient did not decrease from its original value of $3000 \mathrm{~mL} / \mathrm{g}$ until the resin had been exposed to $>10^{7}$ rads. Above these dose levels, the resin distribution coefficient quickly becomes unacceptable. By $10^{8}$ rads accumulated dose, the distribution coefficient drops to 900 and $100 \mathrm{~mL} / \mathrm{g}$ for the 1994 and 1987 tests, respectively. CS-100 was studied in NCAW simulant and shows only a $20 \%$ reduction in the $\mathrm{K}_{d}$ over a similar range as $\mathrm{R}$ $F$ (exposed to $10^{8}$ rads). It should be noted that even after the significant decrease due to a radiation exposure of $10^{8}$ rads, R-F still has a higher Kd than CS-100. 


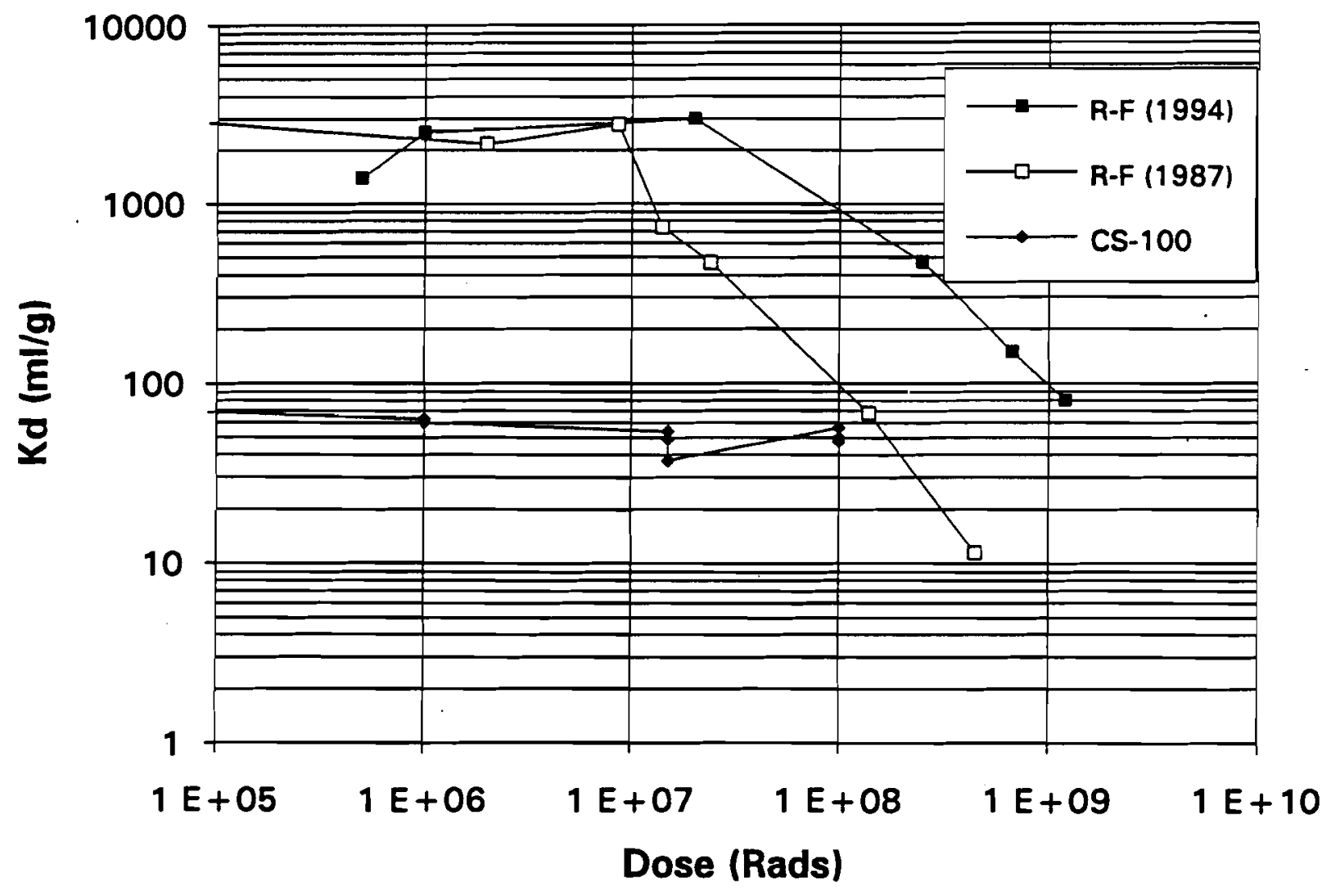

FIGURE 3.1. Cesium Batch Kd for CS-100 and R-F as a Function of Gamma Dose. Kd Taken with NCAW for CS-100 and a $6 \underline{\mathrm{M}}$ $\mathrm{Na}^{+}, 1.5 \mathrm{M} \mathrm{OH}, 2 \times 10^{-4} \underline{\mathrm{M}}$ Cs Solution for R-F Runs. 


\subsection{CONCLUSIONS AND RECOMMENDATIONS}

There are very few commercially available ion exchange materials which are suited for cesium removal from alkaline supernates. Among those studied, CS-100, R-F, C-3, and zeolites may be acceptable, but these materials are not without their limitations. R-F resin has reasonable ion exchange performance, but concerns remain with respect to its elutability in a column, and chemical and radiolytic stability. C-3 has reasonable ion exchange performance, but showed poor elution behavior. The zeolites have $K_{d}$ values as high as CS-100, but appear to be unstable in the highly alkaline solutions which comprise most of Hanford's supernates and saltcakes. Furthermore, if the zeolites are used once-through, they may produce unacceptable quantities of HLW glass.

Work should be done to address the limitations of these exchangers. The chemical and radiochemical stability of R-F should be verified with the new batch of R-F resin (BSC-210). The channelling during elution may not be a significant concern in the larger columns during actual operation. Furthermore, the levels of chemical and radiochemical degradation which are seen with R-F may be acceptable from a processing standpoint.

Only limited data is available on C-3 resin. It was eliminated for consideration for Bplant because it was available only by special order. Since all of the promising organic resins are only available by special order, it should be considered as a viable alternative to CS-100. Although it does not appear much better than CS-100 in terms of its cesium distribution coefficient, further study may show it has other advantages over CS-100. If this resin is investigated, laboratory work should be done to confirm earlier batch distribution and elution results, and the kinetics and chemical compatibility of the C-3 resin should be tested.

Although zeolites degrade in acid eluant, the cesium may be effectively eluted and the zeolites disposed of a LLW glass. This would reduce their impact to HLW glass. This option as well as other similar elution strategies should be considered. 


\subsection{REFERENCES}

Bibler, J. P. 1994a. Year-End Report for UST: Cesium Extraction Testing Project DOE/DT\&E TTP No. SR1-03-20-01 (U) WSCR-RP-94-146. Westinghouse Savannah River Company, Aiken, South Carolina.

Bibler, N. E. and C. L. Crawford 1994b. An Investigation of the Radiolytic Stability of a ResorcinolFormaldehyde Ion Exchange Resin WSRC-RP-148. Westinghouse Savannah River Company, Aiken, South Carolina.

Bibler, J. P. (SRL), R. M. Wallace (SRL), and L. A. Bray. 1990. "Testing A New Cesium-Specific Ion Exchange Resin For Decontamination of Alkaline-High Activity Waste." Waste Management '90, Tucson, Arizona.

Bray, L. A., L. K. Holton, T. R. Myers, G. M. Richardson, and B. M. Wise. 1984. Experimental Data Developed to Support the Selection of a Treatment Process for West Valley Alkaline Supernatant. PNL-4969. Pacific Northwest Laboratory, Richland, Washington.

Bray, L. A., R. J. Elovich, and K. J. Carson. 1990. Cesium Recovery Using Savannah River Laboratory Resorcinol-Formaldehyde lon Exchange Resin. PNL-7273. Pacific Northwest Laboratory, Richland, Washington.

Bray, L. A., K. J. Carson, R. J. Elovich, and D. E. Kurath. 1992. Equilibrium Data for Cesium Ion Exchange of Hanford CC and NCAW Tank Waste. TWRSPP-92-020. Pacific Northwest Laboratory, Richland, Washington.

Bryan, S. A., S. R. Adami, L. A. Bray, C. D. Carlson, J. R. DesChane, R. J. Elovich, and M. R. Telander. 1993. Radiation Testing of Organic Ion Exchange Resin CS-100. TWRSPP-93073. Pacific Northwest Laboratory, Richland, Washington.

Chilton, J. M. 1981. The Use of a Phenolic-Carboxylic Acid Cation Resin in the Treatment of Low-Level Liquid Waste at Oak Ridge National Laboratory. ORNL/TM-7524. Oak Ridge National Laboratory, Oak Ridge, Tennessee.

Gallagher, S. A. 1986. Current NCAW Ion Exchange Laboratory Data. Letter 65453-86-088. Rockwell Hanford Operations, Rockwell International, Richland, Washington.

Goheen, R. S., and D. E. Kurath. 1994. Conceptual Study of In-Tank Cesium Removal Using an Inorganic Ion Exchange Material. TWRSPP-94-015. Pacific Northwest Laboratory, Richland, Washington. 
Griffiths, P. G., C. P. Jones, A. R. Junkison, R. I. Taylor, and M. J. Lain. 1994. An Assessment of the Benefits of the Electrochemical Ion Exchange Process for the Removal of Caesium from the Hanford Waste Supernate. AEA Technical Products Division, Harwell, UK.

Kurath, D. E., L. A. Bray, K. P. Brooks, G. N. Brown, S. A. Bryan, C. D. Carlson, K. J. Carson, J. R. DesChane, R. J. Elovich, A. Y. Kim. 1994. Experimental Data and Analysis to Support the Design of an Ion Exchange Process for the Treatment of Hanford Tank Waste Supernatant Liquids. TWRSPP-94-094. Pacific Northwest Laboratory, Richland, WA.

Marsh, S. F., Svitra, Z. V., and S. M. Bowen. 1994. Distributions of 14 Elements on 63 Absorbers from Three Simulant Solutions (Acid-Dissolved Sludge, Acidified Supernate, and Alkaline Supernate) for Hanford HLW Tank 102-SY. LA-12654. Los Alamos National Laboratory, Los Alamos, NM.

Marsh, S. F., Svitra, Z. V., and S. M. Bowen. 1994. Report to be Published. Los Alamos National Laboratory, Los Alamos, NM.

Perry, R. H., and C. H. Chilton. 1973. Chemical Engineering Handbook. 5th Ed., McGraw-Hill Book Co., New York, New York.

Prignano, A. L. 1989a. Results of Batch Contact Tests on Backup Resins for Removal of Cesium from Synthetic NCAW. Letter Report 12712-PCL89-130. Westinghouse Hanford Company, Richland, Washington.

Prignano, A. L. 1989b. Maximum Cesium Loading Capacity of Four Resins. Letter Report 12712PCL89-158. Westinghouse Hanford Company, Richland, Washington. 
APPENDIX A

ION EXCHANGER MANUFACTURER INFORMATION 


\section{APPENDIX A}

\section{ION EXCHANGER MANUFACTURER INFORMATION}

- Amberlite is a registered trademark of Rohm and Haas, Philadelphia, PA, (215) 5923000 .

- Duolite is a registered trademark of Rohm and Haas, Philadelphia, PA, (215) 592-3000.

- Durasil is a registered trademark of GTS Duratek, Columbia, MD, (410) 312-5100.

- Lewatit is a registered trademark of Miles, Inc., Pittsburgh, PA, (412) 777-2000.

- Ionsiv is a registered trademark of UOP, Mt. Laurel, NJ, (609) 727-9400.

- $\quad$ Boulder Scientific Company, Mead, CO, (303) 535-4494.

- $\quad$ ResinTech, Inc., Cherry Hill, NJ, (609) 354-1152.

- Vydac, The Separations Group, Inc., Hesperia, CA, (619) 244-6107.

- Pharmacia Biotech, Piscataway, NJ, (800) 526-3593.

- $\quad$ Purolite Company, Bala Cynwyd, PA, (215) 668-9090.

- Sybron Chemicals, Birmingham, NJ, (609) 893-1100.

- Dow Chemical Company, Midland, MI, (517) 636-1000. 


\section{APPENDIX B}

ION EXCHANGER TECHNICAL DATA SHEETS 


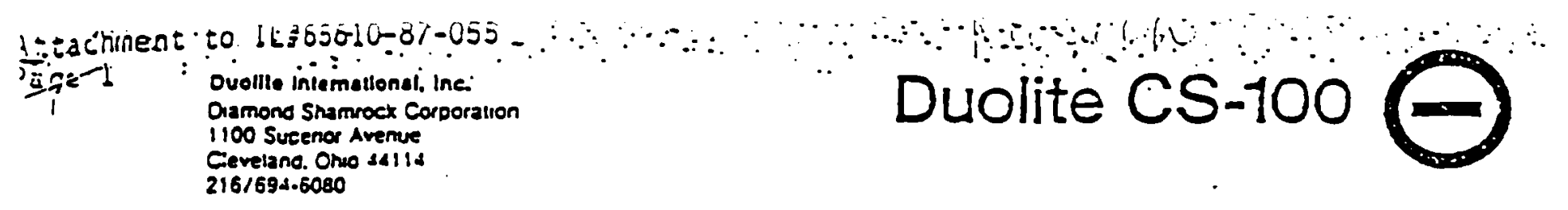

\section{Diamond Shamrock Weak Aeld Callon Exenange Resin \\ (2) Diamond Shamrock •

\section{Technical Sheet}

1923

\section{Product Description}

Duolite CS-100 is a granulap weak-acid catlon exchange resin containing both carboxylic acid and phenolic hydroxyl groups. Because of its unusually high selectivily lor cesium and multivalent cations. this resin is partlcularly effective for the treatment of alkaline low level radioac:ive waste solutions. This high degree of selectivity may suggest other uses lor this unique resin.

Duolite CS-100 has a rigld macroporous structure which is unusually resistant to attrition. Because it swells much less than most weak-acid cation exchangers. very little resin breakdown is encountered in acid-base cycling. Phenolic reslns are more resistant to radiatlon than ootystyrene exchangecs. Duolite CS-100 is easily and completely converted to the hydrogen form with little more than stoichiometric quantities of mineral sclds,

Table 1.

Physical and Chemical Characteristics of Duolite CS-100

Resin matrix.

Functional groups

lonic torm. as shipped

- Physical lorm

- Particié size (moist)

Bulk density, H form: -.-

Molsturs retenitón capacity

Void Volume :".

Carboxylic and phenolic

Hydrogen (other forms on request)

Porous granules

$0.3-1.3 \mathrm{~mm}$. (16-50 mesh, U.S. standard sieves)

600-700 grams (moist)/liter 3.S.20.

(38-45 los/cu. IL)

48-58\% (H lorm)

Maximum reverslble swelling. $\mathrm{H}$ to $\mathrm{Na}$ inim

$40 \%(0.41 / 1$ or 3 gal/cu. 1t.)

Total ion-exchange capacity .

Operating pH range

$20-25 \%$ (e.9., 1.0 $\rightarrow-1.23$ )

Minimum $1.0 \mathrm{eq} / 1\left(22 \mathrm{Kgr} / \mathrm{eu}\right.$. it., as $\left.\mathrm{CaCO}_{3}\right)$

Chemical stability:

:

Resistance-to most acids $\quad \ldots . . \quad$. excellent

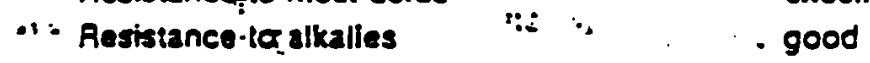

Maximum chiorine concentration . : $: 0.1 \mathrm{ppm}$

$\therefore \quad$ Maximum $\mathrm{HNO}_{2}$ concentration $\therefore$. : .

$1.0 \mathrm{M}\left(\mathrm{at} 25^{\circ} \mathrm{C}\right)$

Low-Level.Radioactive Wăšte Treatment

The presence of ifitehenolle nydroxyl grouo increases ine selecivity ol this resin for cesium by a lactor of io 10 Tou, this very weakly acidle group is activated at $\mathrm{pH}$ values above 9. For Inis reason. Duolite CS-100 has been particularty useful in the selective removil of Cs-137 (and Sr-go) from alkaline low-ievel radioactive wastes. This process. developed originally at the Oak Ridge National Laboratory (1), consists of precipilation with alkall to ramove suispended solids and hardness, sludge removal. inen filtration through a column of . Duollte CS-100 to remove residual radionuclldes. The resin is elfecively regenerated with dilute solutlons of nitric. hydrochloric or sulfuric acids. Based on the published reports. ihis scavenging-precipitation ionexenange process removes more than $99.9 \%$ of the cesium and strontium to levels well below the maximum permissible concantration (MPC) of these radionuclldes.

(1) ORNL-3036. OANL-TM-S, ORNL-3322, OANL-3949, OANL-3863. 


\section{:echnical Sheet}

he decontamination lactors for cesium and strontium with Duolite CS-100 have been in the range of 109 10 104. Capacity is influenced by the presence of othet multivalent catlons since they compele lor the sxchange sites. Thus the overall performance ol the above system depends considerably on the elficiency of ine flocculation and filtration. Any hardness ions present will reduce the ion-exchange capacity for cesium and strontium. II this problem occurs. residual hardness can be removed by using a column of Duolite $C-464$ prior 10 the Ouolite CS-100. Duolite C-464 in the peimary position will șelectively remove the divalent cations (including strontium): Duclite CS-100 will then selectively remove cesium. Both resins are ellectively regenerated (in series) with dilule $\mathrm{HNO}_{3}$ or $\mathrm{HCl}$. Some operating conditions for low level waste treatment with Duolite CS-100 are given in Table 2.

Table 2.

Operating Conditions for Duolite CS-100 in the Treatment of Low Level Radioacilve Waste

Bed depth:

Height to depth ratio:

Service flow rate:

Solution pH:

Volume throughout:

\section{Aegeneration:}

Ainse:

Conversion to sodlum form:
Minimum $90 \mathrm{~cm}$ (36 inches)

$2: 1$ to 10:1

' 12 to 20 iltersniter/he ( 9.5 to $2.5 \mathrm{gom} / \mathrm{cu}$. (t)

112 to 12.0

1500 to 6000 bed volumes

(\$1,000 10 45,000 gals/cu. It)

$0.5 \mathrm{~N} \mathrm{HNO}_{3}, 10$ to 15 bed volumes

(Dilute $\mathrm{HCl}$ and $\mathrm{H}_{2} \mathrm{SO}$, have also been used)

One bed volume soft water

20 bed volumes of $0.1 \mathrm{~N} \mathrm{NaOH}$

\section{Adsorption of Organic Compounds}

The unique properties of Duolfte CS-100 suggest its use in the isolation or chromatographie separation of organic compounds such as the basie amino acids (arginine, histidine and lysine). alkaloids (nicotine and quinine), vilamins (thiamine, nicotinamide. adenine, folic acid and $B_{12}$ ) and erzymes. These substances can be acsorbed by either the hydrogen or sodlum form of the resin and are eluted by near stoichiometrie amounis ol dliute acid (or alkali). In general. the hydrogen lorm is suggested lor adsorptlon ol compounds in the tree-base lorm whereas the sodlum form is more elfectlve in the adsorption of actdic salts.

In an interesting application (2). coenzyme A was adsorbed by Duolite CS-100 from an acidic solutlon, the impurities stripped olf with $0.2 \mathrm{~N} \mathrm{HCl}$, and the coenzyme eluted off with water.

(2) J. Am. Chem Soc 74.854 (19S2). 


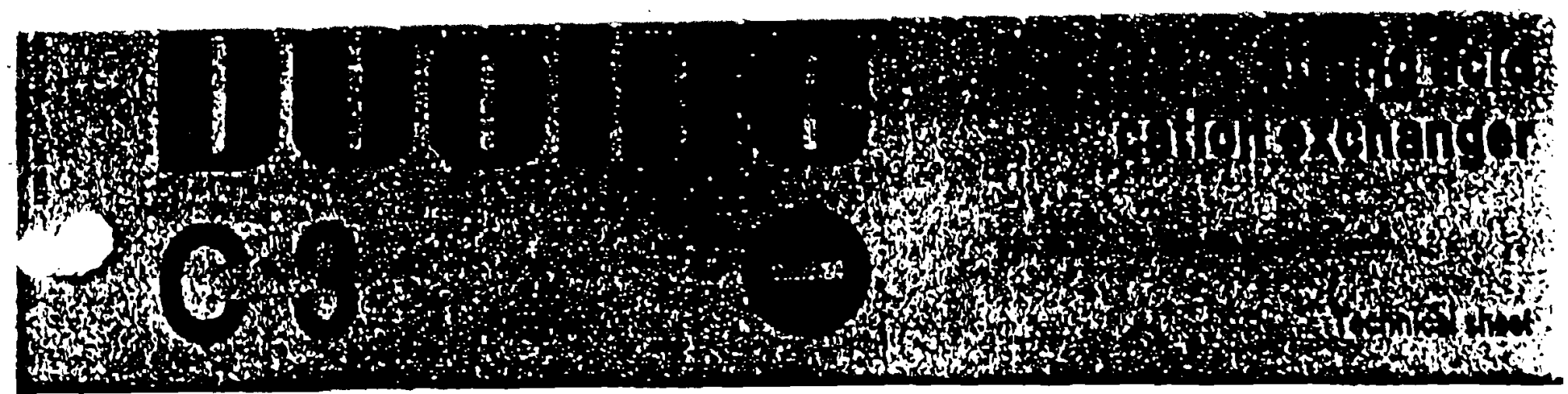

Duollte Internatlonal SA, a Unit of Fohm and Haas Company

\section{PAODUCT DEBCAIPTION}

DUOLITE C 3 is a highly porous strongly acl. dic cation oxchange resin bassd on crosalin. ked phenol-formaldehyde polycondensate, in granular form. The contlouration of this resin diffors algnifleantly from that of a polystyrene catlon exchanger: the funotlonel groups of Quollte C 3 aro methylene sulphonle rathor than benzene sulphonle. This has a favourable influence on the regeneration officlency, the selectlvity and the adsopptivity. The highly porous matrlx of DUOLITEC 3 comblned with lis sorptive propertles makes it particularly useful where combination of cation exchange and adsorptlon is necessary.

\section{PROPERTIES}

Reoln matrlx

Functlonal groups

Appearance

Specifle gravity

Bulk density

Particle slzo

Ionic form as anlpped

Molature rotention capacity

Total exchange capacity

Roverstble swelling

Pressure drop per matre of bed

depth

Hydraulle expanglon
Crosslinked phenol-formaldehyde Dolycondensato

Mothylene sulphonic

Dark red granules (wol)

1.24 (H form)

700 to 770 g/litere (fully hydrated)

0.3 to $1.4 \mathrm{~mm}$ (fully hydrated)

Hydrogen

$451068 \%$ (fully hydrated $H$ form)

$1.009 /$ litre (wot)

$2.800 / \mathrm{kg}(\mathrm{dry})$

Approx. 3 \% (from sodlum 10 hydrogen (orm)

Approx. $2 \mathrm{kPa}$ per $\mathrm{m} / \mathrm{h}$ linear flow rato (water, $20^{\circ} \mathrm{C}$ )

Approx. $60 \%$ at $16 \mathrm{~m} / \mathrm{h}$ (water, 20\% ) 
arratuitios

The princlpal uses of DUOLITE C 3 are in the nuclear, starch hydrolysates and pharmaceu. tleal industries.

Nucleap Power 8tations:

Ceeslum removal.

8lareh Hydrolyeates Induetrles:

Taste and odoup removal, refining, HMF romoval.

Pharmuceutleal Industries:

Chromatographic separation of amino acids and alkaloids.
Food Procenaing Applications:

OUOLITE C 3 complles compositionally with the US regulation FDA 21 CFR 173.25. As governmental pegulationa vary from country io couniry, It is pecommended that potentlal users of resins for food procesaing appllestions contact their Ouollte representative 10 assess the beat cholce of resin and optimum operating conditions.

\section{OUQOEgTEO OPEAATINO CONDITIONB}

$\begin{array}{ll}\text { pH range: } & 0 \text { to } 13 \\ \text { Temperature llmitation: } & \max 80^{\circ} \mathrm{C} \\ \text { Minimum bed depth: } & 700 \mathrm{~mm}\end{array}$

Bervlee flow rato:

- When treating high viscosity llquors or high lovels of Impurities: up to $8 \mathrm{BV} / \mathrm{h}$

- With low viscosity llquors of low levels of Impurties:

Regenorallon:

Regenorants

Regeneration lovel g/litre resin

Concentration $w / \mathrm{v}$

Flow rate

Minimum contact time

Rinse flow rate

8 to $24 \mathrm{BV} / \mathrm{h}$

$\begin{array}{ll}\mathrm{H}_{2} \mathrm{SO}, & \mathrm{HCl} \\ 50 \text { to } 100 & 40 \text { 10 } 80 \\ 2 \text { to } 4 \% & 2 \text { to } 8 \% \\ 2108 \mathrm{BV} / \mathrm{h} & \\ 30 \mathrm{minutes} & \\ 10 \text { gV/h (2 BV displecement at } \\ \text { regeneratlon flow rate) }\end{array}$

\section{Romurke}

1. In speclal ceses, In order to reactlvate totally the surface adsorption propertles of DUOLITE C 3, a perlodle dliute cauatle finse before the acld regeneration le recommended.

2. Combinations of factors such as strong oxldlzing agents, hlgh pH and elevated tempera- tupe can produce undeslrable eifects on the llte tlme of the resin.

3. Volume dellvered is measured in the fully hydrated form, after bolng exhausted with dilute NaOH solution, regenerated (800 above), beckwashed extensively, settled and drained. gefo Hendling Information:

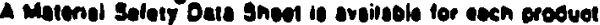
upan raques.

\section{Cavilon:}

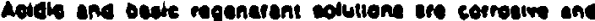

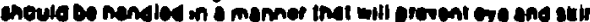
eonerece

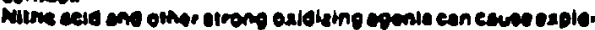

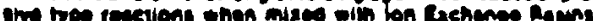

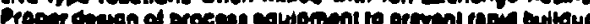

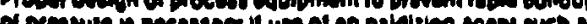

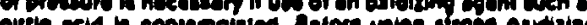

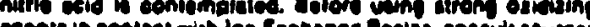

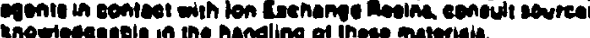

All intormetion, recommencetions ang sugoestions coone.

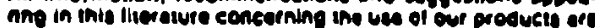

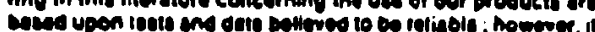

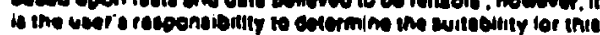

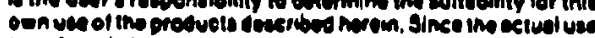

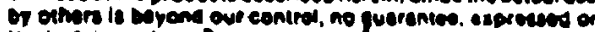

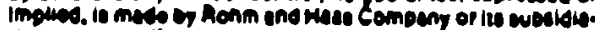

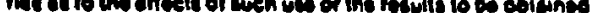

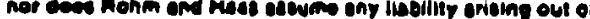

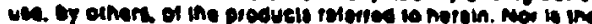

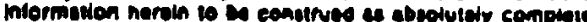

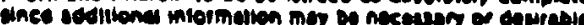

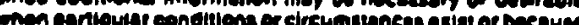

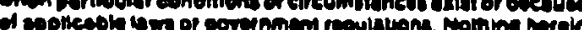

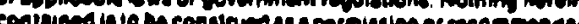

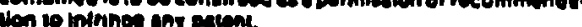




\section{Produktinformationen}

Gelformiger Kationenaustauscher nalt gemischl sauren Gruppen aut Basis einas Polyteondensationzs/uer \&ey, oereinial und ausgewaschen entsprechend den Spezilikationen der Korntochnik, für Jurr Eirsale in

Elnzelbent-Flitem zur coloktiven Cossiumbindung aws

Losungen mir großen Mengen an Alkallinnan

Dekonteminierung von

Kroislisten in kemtechnischen Anlagen

j)

bai Filtrationsgesehwindigkeiten bis $40 \mathrm{~m} / \mathrm{h}$ und Detriebstemperalurers Lis $50^{\circ} \mathrm{C}$.

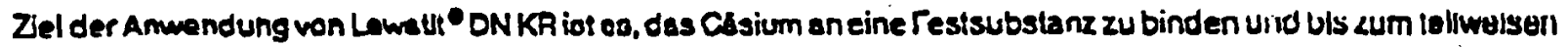
Aoklingen der Hadloaktlwtht sirhar si! lagem. Es ist daher im allgemainen keine Regencrution des Austauseners vorgesution.

Dle Bestandigkeil Jes Lewatit ON KA nimmt mit steigendem pH-Wen ab. Dies zaigt sich an einer zunehmendon Peptization, die bei pll-Werten über 11 zur Utultichen Vertarbung des aufbereitelen Wassers lühn.

Wirehilge Produktdaten und Emplohlungen zum Betrieb von Lewelil DN KR sind aul der ROchselte dieses Blanes. zusemmengestelk

Spczifikation for den Ginsaz in keyliteclunlscthen Anlagen:

Gahall an Chlorid und organisch gebundenom Chibr $\max 300 \mathrm{mg} / 1$

Strahlenbestandigkelt Matrix $\quad 10^{n}-10^{\circ} \mathrm{ruJ}$

Strahlenbestandigkeit Funktionello Gruppen $10^{6}-10^{2}$ rad

Die Leiolung der kn-l larze wird wesentlich auch von dar Konstrukalon der Apparaturcn. der Vertahrensterhnik $\ldots$ und den Anfordenungein an das auneruitete Wasser im Verhaltnis zu don Zutautwerten bevinllubt. 
Lewratit DN KA

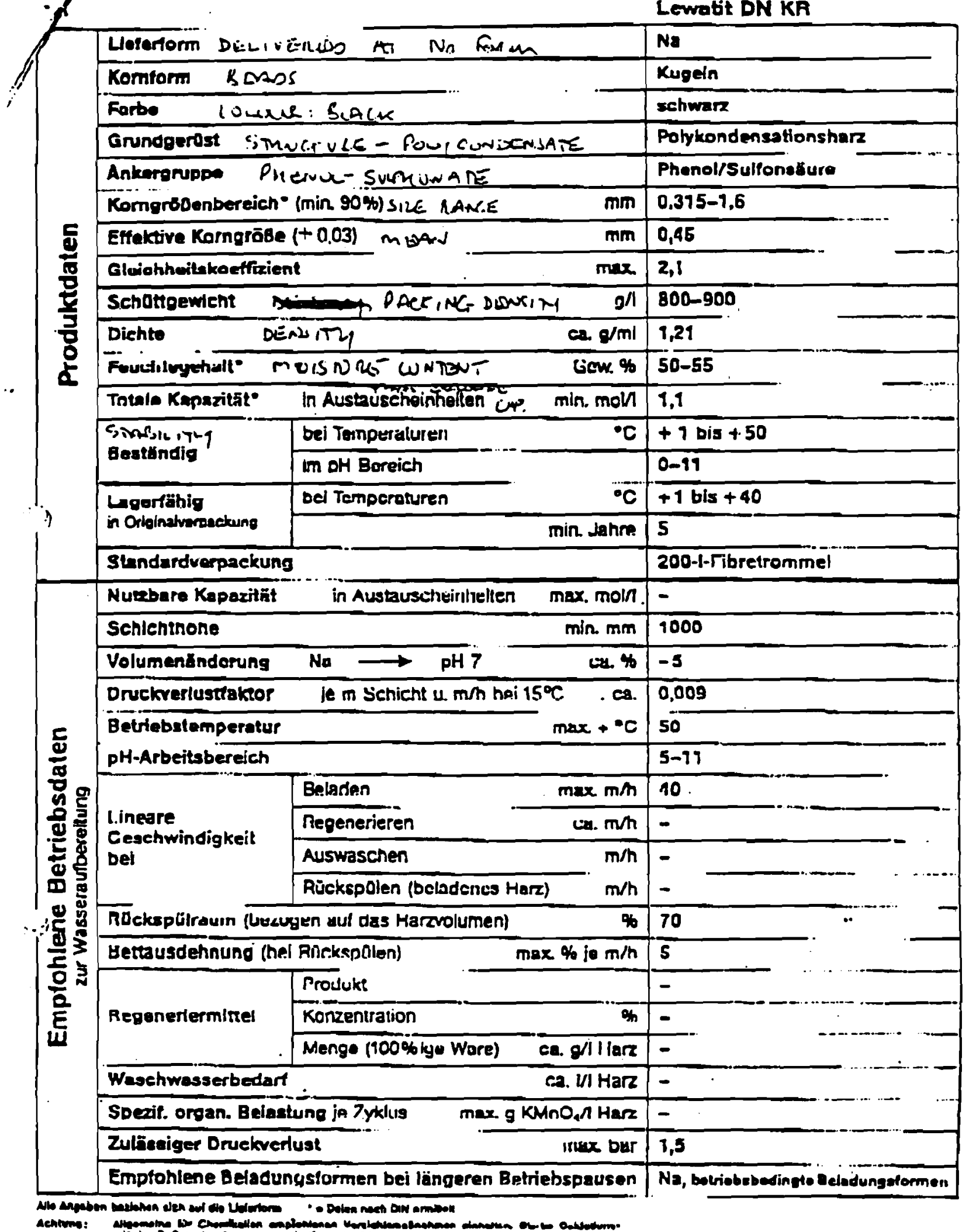

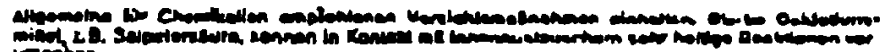
Gentan

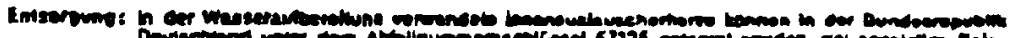

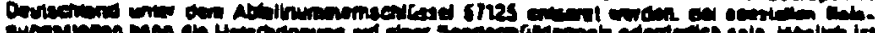

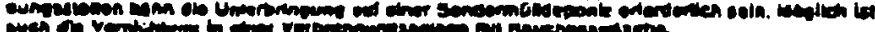

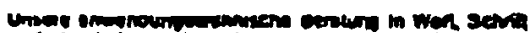

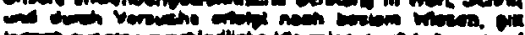

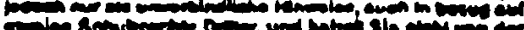

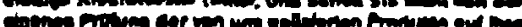

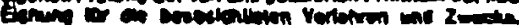

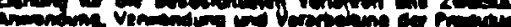

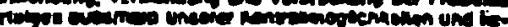

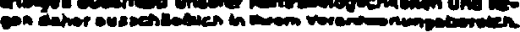

Kein oethriticlies natupurlgut

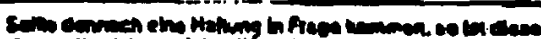

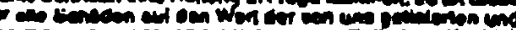

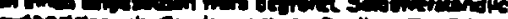

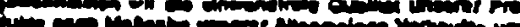

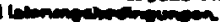

umanes Januer 1080

Purene: jenuer 198 


\section{Ion Exchange Resins}

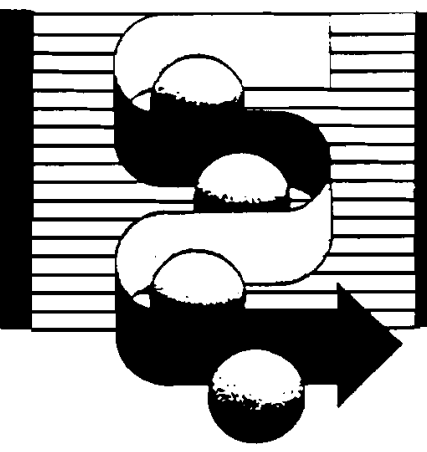

\section{AMBERLITE ${ }^{\circ}$ IRC-718}

AMBERLITE IRC-718 chelating cotion exchonge resin has a high offinity for heavy metal cations over alkali or alkaline earth metals, such os sodium, potossium, calcium and magnesium. Selectivity is achieved by an iminodiacetic acid tunctionality chemically bonded to a mocroreticulor resin motrix. The functional group coordinates heavy metal ions with several active sites, binding the ions very tightly.

The selective noture of AMBERLITE IRC-718 resin moy dramotically decrease the cost of waste treatment. When small amounts of toxic metals are in solution with larger amounts of alkali or alkoline earth cotions, AMBERLITE IRC-718 resin will prefer the toxic metals over the other cations. This allows removal of the undesirable metal contaminant without the need to completely deionize the waste stream. Regeneront costs and, in some coses, copital costs can be reduced, since o smaller system can be used.

The mocroreticular structure of AMBERLIE IRC-718 resin provides a number of odvantages over traditional gel resins. It is highly resistant to osmotic shock providing greater resin life than gel resins used under the same conditions. Due to the short ion diffusion path, the high porosity of AMBERLIIE IRC-718 resin improves the kinetics of ion exchange.

AMBERLTE IRC-718 resin is ideal for use in nonoqueous media, such as chemical process streams, because of its macroreticular structure. The resin is based on o very stable styrene-divinyi benzene motrix. Typical physical properties are given in Table 1.

\section{Selectivity}

The apparent selectivity of any ion exchange resin for o given metal depends upon concentration, the presence of other species, and pH. This makes absolute selectivities very difficult to determine, especially for waste treatment applicotions. Because of this, laborotory testing is essential when a resin is required to remove one or more types of metal ions selectively. Selectivities hove been measured under vorious conditions to give starting points for choosing o resin for selective metal removal.

TABLE 1

Typical Physical Properties

(These do not constitute specifications)

\begin{tabular}{ll}
\hline Appearance & Hydrated, opoque beads \\
\hline Shipping Weight & $42 \mathrm{lbs} . / \mathrm{ft} .^{3}$ (No form) \\
\hline Screen Grading (wet) & $\begin{array}{l}16 \text { to } 50 \text { mesh } \\
\text { N.S. Standard Screen) }\end{array}$ \\
\hline Moisture Content & 62 to $68 \%$ (No form) \\
\hline Swelling & $40 \% \mathrm{H} \rightarrow \mathrm{No}$ \\
\hline Cottion Exchange Copocity & $1.1 \mathrm{meq} / \mathrm{ml}$ wet resin \\
\hline
\end{tabular}

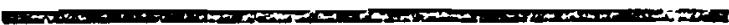

1) $\mathrm{pH}=2$

\begin{tabular}{lc} 
Metalion & \multicolumn{2}{c}{$K_{\mathrm{Co}}^{\mathrm{M}}$} \\
\hline $\mathrm{Fe}+{ }^{++}$ & 325,000 \\
\hline $\mathrm{Cu}^{++}$ & 130,000 \\
\hline $\mathrm{Hg}^{++}$ & $>43,000$ \\
\hline $\mathrm{Au}^{++}$ & 8,100 \\
\hline $\mathrm{Ag}^{+}$ & 4,600 \\
\hline $\mathrm{Ni}^{++}$ & 3,200 \\
\hline $\mathrm{Cd}^{++}$ & 620 \\
\hline $\mathrm{Fe}^{++}$ & 190 \\
\hline $\mathrm{Mn}^{++}$ & 120 \\
\hline $\mathrm{Zn}^{++}$ & 120 \\
\hline $\mathrm{Al}^{++}$ & 50 \\
\hline $\mathrm{Mg}^{++}$ & 20 \\
\hline $\mathrm{Co}^{++}$ & 1.0 \\
\hline
\end{tabular}




\begin{tabular}{|c|c|}
\hline 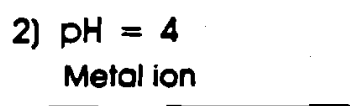 & $K_{C o}^{M}$ \\
\hline $\mathrm{Hg}^{++}$ & 2.800 \\
\hline $\mathrm{Cu}^{++}$ & 2,300 \\
\hline $\mathrm{Pb}++$ & 1,200 \\
\hline $\mathrm{Ni}++$ & 57 \\
\hline $\mathrm{Zn}^{++}$ & 17 \\
\hline $\mathrm{Cd}++$ & 15 \\
\hline $\mathrm{Co}^{++}$ & 6.7 \\
\hline $\mathrm{Fe}^{++}$ & 4.0 \\
\hline $\mathrm{Mn}^{++}$ & 1.2 \\
\hline $\mathrm{Ca}^{+}+$ & 1.0 \\
\hline \multicolumn{2}{|c|}{ 3) $\mathrm{pH}=9$, very high ammonium background } \\
\hline $\begin{array}{l}\left(200 \mathrm{~g} / \mathrm{L}\left(\mathrm{NH}_{4}\right)_{2} \mathrm{SO}_{4}\right) \text {. } \\
\text { Metal ion }\end{array}$ & $K_{C a}^{M}$ \\
\hline $\mathrm{Ni}++$ & 30 \\
\hline $\mathrm{Cd}++$ & 14 \\
\hline $\mathrm{Cu}++$ & 10 \\
\hline $\mathrm{Zn++}$ & 3 \\
\hline $\mathrm{Ca}^{++}$ & 1.0 \\
\hline
\end{tabular}

These doto provide a guideline of relative selectivities; no table can provide selectivities under all conditions. Using these starting points, the affinity of the resin for a given metal can be increased or decreased by adjusting $\mathrm{pH}$.

\section{Operating Conditions}

AMBERLITE IRC-718 resin is widely used in waste treatment, chemical processing. and hydrometallurgical applications where there is high variability in feed streams and competition from other species present in solution. Changes in $\mathrm{pH}$, concentration, and background composition (especially complexing ions such as EDTA) moy change sorption characteristics. The suggested conditions listed in Table 2 should, therefore. be considered a starting point; laboratory experiments should be done to determine the effectiveness of any ion exchange process for a desired application.

\section{Operating Capacity}

The total exchange capocity of AMBERLITE IRC-718 resin in the sodium form is $1.1 \mathrm{meg} / \mathrm{ml}$ wet resin. in normal use, however, the resin bed is usually not completely exhausted during operation, and economic considerations may dictate less than 100 percent regeneration. Actual operating capacity will be less than the total exchange capacity and should be determined by specific applicotions testing.

\section{Backwashing}

Many feed streams contain particulate matter which can clog an ion exchange bed. Bockwashing is necessary ot regular intervals to remove this moterial. When there are large amounts of suspended motter, bockwoshing moy be necessary ot each regeneration cycle. The backwash should be of a sufficient rote to give of least 50 percent bed expansion. The proper flow rate can be found in Figures 3 and 4 .

\section{Exhaustion Flow Rate}

Chelating ion exchange resins may hove slightly poorer kinetic characteristics than conventional (strong electrolyte) ion exchangers. Flow rates.

TABLE 2

\section{Suggested Operating Conditions for AMBERLITE IRC-718}

\begin{tabular}{|c|c|}
\hline \multicolumn{2}{|c|}{$\begin{array}{l}\mathrm{pH} \\
\text { (minimum pH depends on application) }\end{array}$} \\
\hline Moximum Temperature & $\begin{array}{l}190^{\circ} \mathrm{F} .\left(90^{\circ} \mathrm{C}\right)(\mathrm{Na}) \\
160^{\circ} \mathrm{F} .\left(70^{\circ} \mathrm{C}\right)(\mathrm{H})\end{array}$ \\
\hline Senvice Flow Rote & $\begin{array}{l}1.0 \text { to } 4.0 \mathrm{gpm} / \mathrm{tt}^{3} \\
\text { [8.0 to } 32.0 \mathrm{BV} / \mathrm{hr} \text {.] }\end{array}$ \\
\hline Regeneration & $\begin{array}{l}5 \text { to } 15 \% \mathrm{HCl} \text { or } \mathrm{H}_{2} \mathrm{SO}_{4} \\
0.25 \text { to } 0.50 \mathrm{gpm} / \mathrm{ft}^{3} \\
\text { (2.0 to } 4.0 \mathrm{BV} / \mathrm{hr} \text {.) } \\
6 \text { to } 12 \mathrm{lbs} . \mathrm{acid} / \mathrm{ft}^{3}\end{array}$ \\
\hline $\begin{array}{l}\text { Neutralization } \\
\text { (if necessary) }\end{array}$ & $\begin{array}{l}1 \text { to } 3 \% \text { sodium hydroxide } \\
\text { or ammonium hydroxide } \\
0.25 \text { to } 0.50 \mathrm{gpm} / \mathrm{tt}^{3} \\
\text { (2.0 to } 4.0 \mathrm{BV} / \mathrm{hr} \text {.) } \\
2 \text { to } 4 \mathrm{lbs} . / \mathrm{Ht}^{3}\end{array}$ \\
\hline Pressure Drop & See Figures 1 and 2 \\
\hline $\begin{array}{l}\text { Hydraulic Expansion } \\
\text { During Bockwash }\end{array}$ & See Figures 3 and 4 \\
\hline
\end{tabular}


Flgure 1.AMBERLIIE IRC-748

SODIUM FORM HMS-0.55

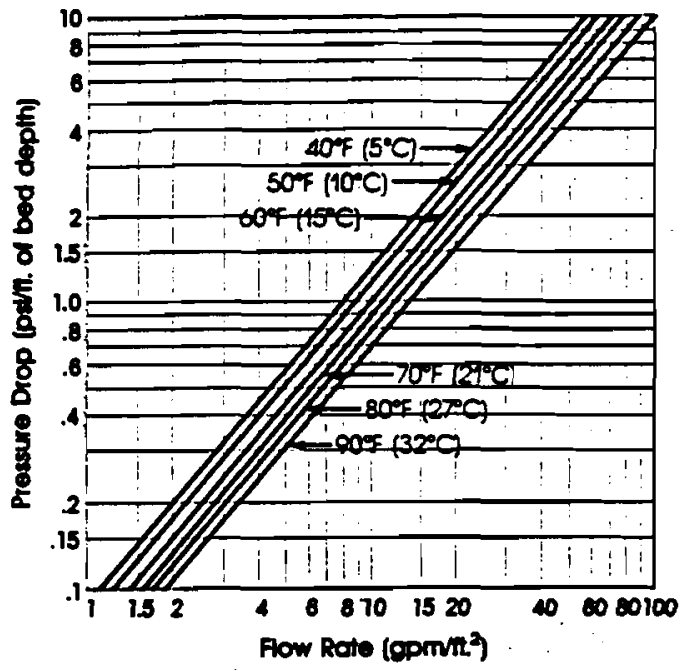

Figure 2AMBERLTE IRC-748

HMDROGEN FORM HMS- 0.54

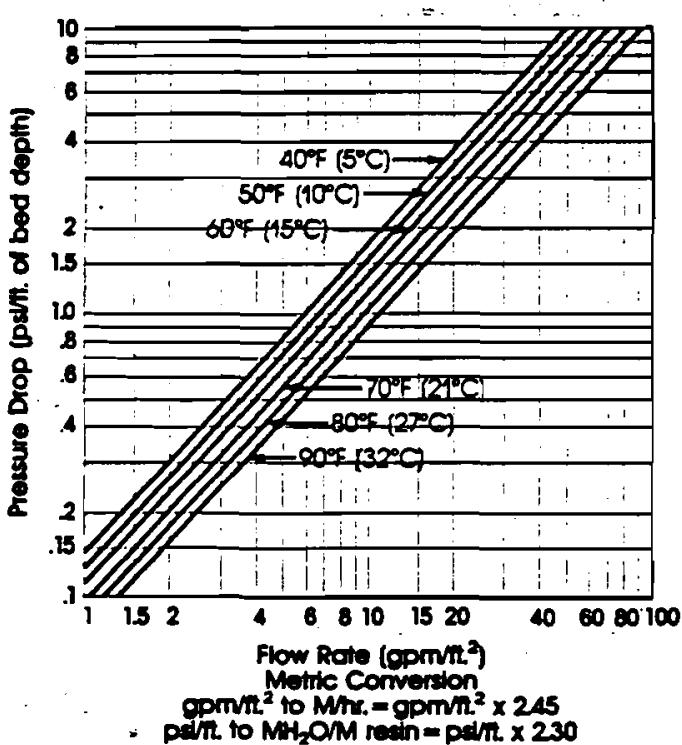

FIgUTE 3 HMORAUUC EXPANSION OF THE SODIUM FORM OF AMBERLTE IRC-718
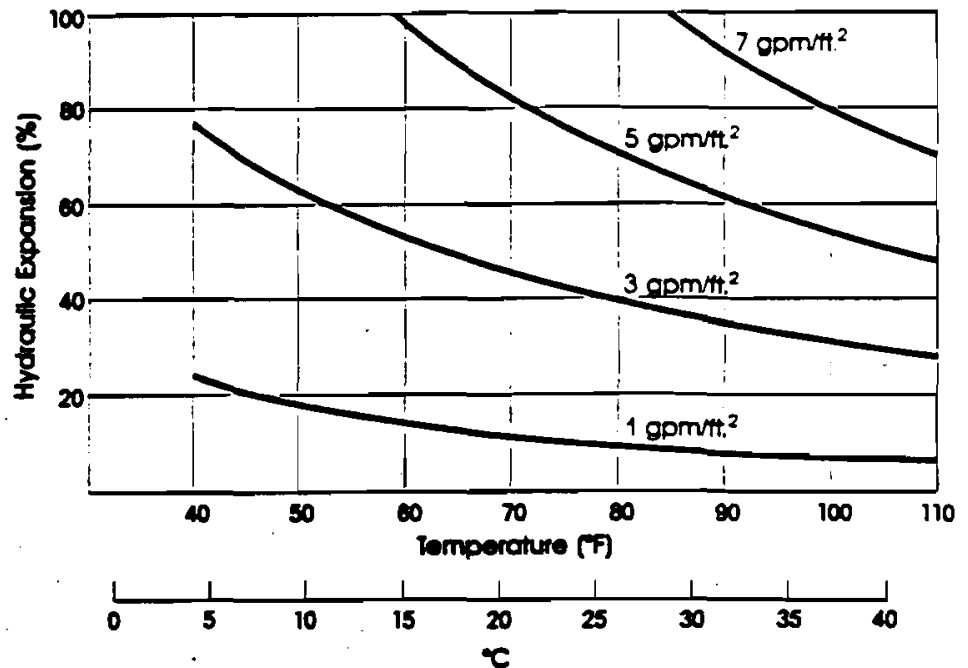

Foure 4 HMDRAUUC EPANSTON OF THE HMDOCEN FORM OF AMBERUIE IRC-718

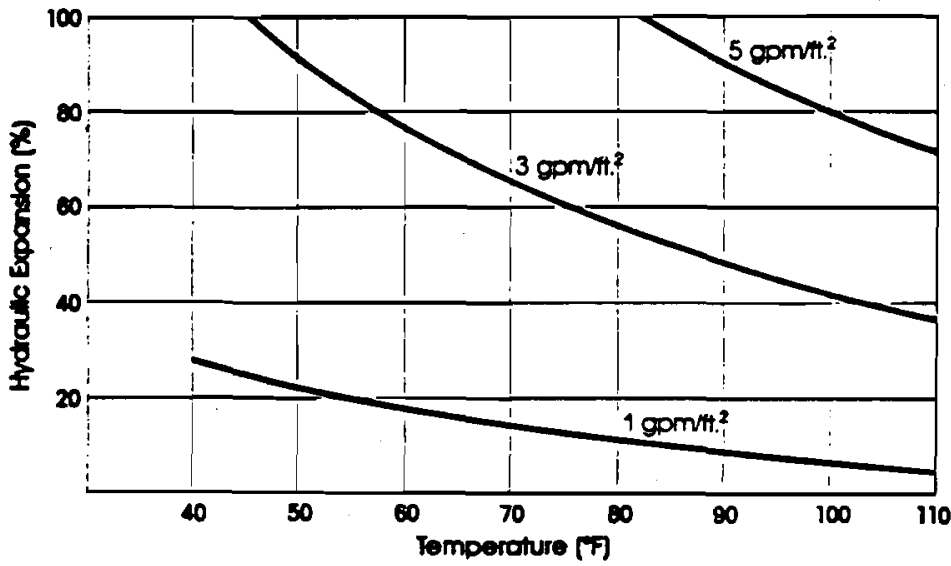

Moitic Comversion $\operatorname{comm}{ }^{2}$ to Mhr. $=\operatorname{comm}^{2} \times 245$

therefore, may need to be somewhot slower than would be typical for woter treotment resins. Flow rates of 1.0 to $4.0 \mathrm{gpm} / \mathrm{ft}^{3}{ }^{3}$ (8.0 to $32.0 \mathrm{BV} / \mathrm{hr}$.) should be acceptable for less demanding applicotions but should be reduced when high flow rotes prevent efficient removal of the heary metal ions.

\section{Regeneration}

Becouse AMBERLITE IRC-718 resin has an extemely high affinity for metal ions, the amount of acid required is higher than that required for conventional weakly acidic ion exchange resins. $A$ regeneration level of 6 to $10 \mathrm{lbs}$. $\mathrm{HCl} / \mathrm{ft}^{3}$ moy be 
sufficient for metals with moderote selectivity, but this should be increased slightly for tightty held metals. Flow rates of 0.25 to $0.5 \mathrm{gpm} / \mathrm{ft}^{3}$ [2.0 to $4.0 \mathrm{BV} / \mathrm{hr}$.) provide the best results. Acid concentration should be 5 to 15 percent, with higher concentrations needed for more tightly bound species.

\section{Neutralization}

Because it is a weakly acidic cheloting resin, AMBERLITE IRC-718 resin moy require neutralization offer acid regenerotion. The resin should be rinsed after acid regenerotion with several bed volumes of woter, then treated with 2 to $4 \mathrm{lbs} . / \mathrm{ft}^{3}{ }^{3}$ of 1 to 3 percent sodium hydroxide or ammonium hydroxide. Neutralization may not be necessary for tightly bound ions or when the $\mathrm{pH}$ of the influent is high. Laboratory tests on individual influent compositions will indicate whether neutralizotion is needed.

\section{Commissioning New Resin}

AMBERLITE IRC-718 resin is supplied in the sodium form and can, therefore, be used immediately ofter rinsing with several bed volumes of woter.

\section{Suggested Applications}

Chlor-alkall Industry. AMBERLITE IRC-718 resin effectively removes hardness to less than 50 ppb from brine that is fed to chlor-alkali electrolysis cells, although an aminophosphonic resin (such as DUOLITE C-467) should be used for maximum performance.

Purificatlon of Process Streams Containing Trace Heary Metals. Objectionable levels of metals moy be present in process streams due to their use as cotalysts and their presence in row mote- rials. The high surface area and good selectivity of AMBERLITE IRC-718 resin, as well as its ability to remove metals over a wide $\mathrm{pH}$ range, make it a good choice for this application.

Electroplating Industry. The high selectivity of AMBERLITE IRC-718 resin for heovy metals is useful in the removal and recovery of metal ions from plating boths and rinse waters common to the plating industry. The macroreticular structure of this resin ensures its stability in the aggressive solutions of ploting boths.

Recovery of Heavy Metals trom Hydrometallurgical Leach Streams. Becouse of the ability of AMBERLITE IRC-718 resin to function over a wide $\mathrm{pH}$ range, it can be used to recover heow metal cations that have been leached from ores by acids or bases. Elution of metals from this resin is extremely efficient, yielding a concentroted solution of the desired metal ion.

\section{Sofe Handling Information}

A Moterial Sofety Dota Sheet is ovailable for AMBERLITE IRC-718. To obtain a copy contact your Rohm and Hoas representative.

CAUTION: Acidic and basic regenerant solutions are corrosive and should be handled in a manner that will prevent eye and skin contact.

Nitric acid and other strong oxidizing agents can couse explosive-type reoctions when mixed with ion exchange resins. Proper design of process equipment to prevent rapid buildup of pressure is necessary if use of an oxidizing agent such as nitric acid is contemplated. Before using strong oxidizing agents in contact with ion exchange resins, consult sources knowledgeable in the handling of these materials.

AMBERLITE and DUOUTE are registered trodemanks of Rohm and Hoas Company, or of its subsidionies or affiliates. The Companys policy is to register th trodemanks where products designoted thereby are marketed by the Company, its subsidionies or atfiliotes.

These suggestions and data are bosed on informotion we believe to be reliable. They are offered in good faith. but without guarontee. as conditions ond methods of use of our products are bevond our control. Wh recommend that the prospective user determine the suitability of our materials and suggestions before adopting them on a commercial scale.

Suggestions for uses of our products or the inclusion of descriptive moterial from potents and the citotion of specific potents in this publicotion should not be understood as recommending the use of our products in violation of any potent or as permission or license to use any potents of the Rohm and Hoos Compony.

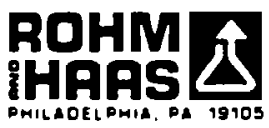


$\Delta$ mberlite IRC-76 resin is a high capacity, weakly acidic, macroreticular cation exchange resin. It has carboxylic acid functional exchange sttes within a crosslinked acrylic matrix. Amberltie IRC-76 resin is supplied as white spherical particles in the hydrogen form. As a weakly acidic resin. Amberlite IRC-76 can split alkaline salts of multivalent cations such as calcium and magnesium, and also alkaline salts of sodium. Amberlite IRC-76 resin combines a very high capacity with lower swelling than is exhibited by conventional carboxylic resins. Amberlite IRC-76 resin offers high regeneration efficiency, excellent chemical stabillty, and high resistance to physical breakdown due to osmotic or mechanical stress.

\section{IMPORTANT FEATURES}

High Capacity

Amberlite IRC-76 resin has an exchange capacity of 4 equivalents per liter.

\section{Excellent Stability}

Amberlite IRC-76 resin has excellent resistance to attrition from osmotic or mechanical stresses.

\section{Stable Over a Wide pH Range.}

\section{High Regeneration Efficiency}

Becouse it is a weakly acidic resin. Amberlite IRC-76 resin can be easily regenerated with slightly more than stoichiometric amounts of dilute solutions of mineral acids. The result is a process which is very chemically efficient.

\section{PHYSICAL CHARACTERISTICS}

Physical Form - Opoque spherical beads, shipped in the hydrogen form. Typical physical properties for Amberlite IRC-76 resin are listed in Table 1.

\section{TABLE 1}

TYPICAL PHYSICAL PROPERTIES OF AMBERLITE IRC-76 RESIN

\section{Type}

Moisture Content, \%

Bulk Density, Ib/ft3

Specific Gravity

Screen Grading (wet)

\% Swelling
$\mathrm{H}^{+}$to $\mathrm{Ca}^{+}$form
$\mathrm{H}^{+}$to $\mathrm{Na}^{+}$form

Total Exchange Capacity, $\mathrm{meq} / \mathrm{g}$ (dry). $\mathrm{meq} / \mathrm{ml}$ (wet)
Weakly acidic, carboxylate cation exchanger

54 to 58

484

1.14

16 to 50 mesh

(U.S. Standard screen)

$15^{1}$ (tull conversion) $60^{\circ}$ (tull conversion)

11

4 'opproximotely 
TABIE 2

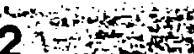

$2 \times 1-1+x^{2}$

SUGGESTED OPERATING CONDITIONS

Service Cycle pH

5 to 14

Maximum Temperature

$250^{\circ} \mathrm{F}\left(120^{\circ} \mathrm{C}\right)$

Minimum Bed Depth

Backwash Flow Rate

Service Flow Rate

24 inches $(0.61 \mathrm{~m})$

See Figure 1

0.5 to $8 \mathrm{gpm} / \mathrm{tt}^{3}$

( 4 to $64 \mathrm{l} / \mathrm{hr} / \mathrm{l}$ )

Regeneration Concentration

Regeneration Flow Rate

Rinse Woter Requirements

Slow Rinse

Fost Rinse
2 to $5 \%(\mathrm{HCl})$,

0.5 to $4 \%\left(\mathrm{H}_{2} \mathrm{SO}_{4}\right)$

0.25 to $1.0 \mathrm{gpm} / \mathrm{ft}^{3}$

(2.0 to $8.0 \mathrm{l} / \mathrm{hr} / \mathrm{l})$

$2 \mathrm{BV}$ ot regenerotion flow rate

4 to $8 \mathrm{BV}$ at senvice flow rate

- These suggestions cover the mojority of conditions encountered in operating units. Some situations may require operation outside these parameters (e.g. regenerant flow rote). Recommendations concerning operations of this noture snould be sought from the equipment supplier, a knowledgeable consultant or your local Rohm and Haas technical representative.

\section{APPLICATIONS \\ Dealkalization}

In the hydrogen form Amberlite IRC-76 resin is very effective in removing ions associated with carbonate and bicarbonate alkalinity. This can be accomplished by using Amberlite IRC-76 alone in the hydrogen form or before a strongly acidic cation exchanger operating in the sodium form. A degasifier is placed after the weak acid resin bed to remove carbon dioxide.

\section{Deionization}

Amberlite IRC-76 may be used as the primary cation exchanger in a separate bed, followed by a bed of strong acid resin such as Amberlite IR-120 Plus. This type of operation can provide extremely efficient removal of cotions.

An alternate system using o layered resin bed in a single cation vessel will also ochieve excellent cation removal. This system uses Stratabed" 76 resin with Stratabed 122, a strong acid resin. These two Stratabed cation exchange resins are specially sized for loyered bed operation.

\section{Sottening}

In the sodium form. Amberlite IRC-76 is extremely effective in removing hardness well below the ppm leakoge level even in the presence of high levels of common salt. Regeneration is accomplished with an acid strip followed by a coustic treatment step.

Amberlite IRC-76 can be used directly os a softener, or as a polishing softener following beds of strong acid cation resin such os Amberlite IR-120 Plus. 


\section{HYDRAULIC CHARACTERISTICS}

\section{Bockwash Charocteristics}

To insure proper cleaning and hydraulic classification of Amberlite IRC-76 resin. the resin bed should be backwashed with water atter every operating cycle. Backwash should be continued for about 10 minutes at a flow rate sufficient to expand the bed volume by 50 to 75 percent. Figure 1 shows typical hydraulic expansion curves for Amberlite IRC-76 resin at various flow rates and temperatures.

\section{FIGURE 1}

Hydroulic Expansion of Amberlite IRC-76 Resin Hydrogen form

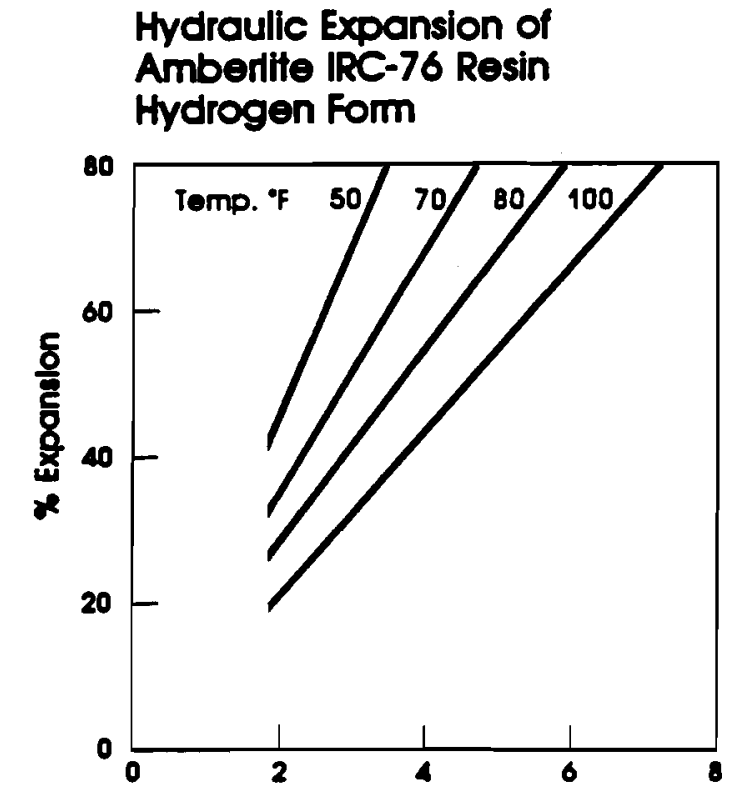

Unear Velocthy, $9 \mathrm{pm} / \mathrm{m}^{2}$

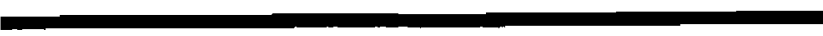

\section{Pressure Drop}

Figure 2 shows the expected clean bed pressure drop per foot of bed depth in normal downflow operation at various flow rates as a function of temperature. The total pressure drop can be estimated by multiplying the pressure drop determined from Figure 2 at the design flow rate by the bed depth in feet.

\section{FIGURE 2}

\section{MATERIAL SAFETY DATA SHEETS}

Material Safety Data Sheets (MSDS) are avait able for all Amberlite ion exchange resins. To obtain a copy for a particular resin we suggest you contact your local Rohm and Haas technical representative or the Rohm and Haas Company.

\section{Approximate Pressure Drop of Amberlite IRC-76 Resin Hydrogen Form}

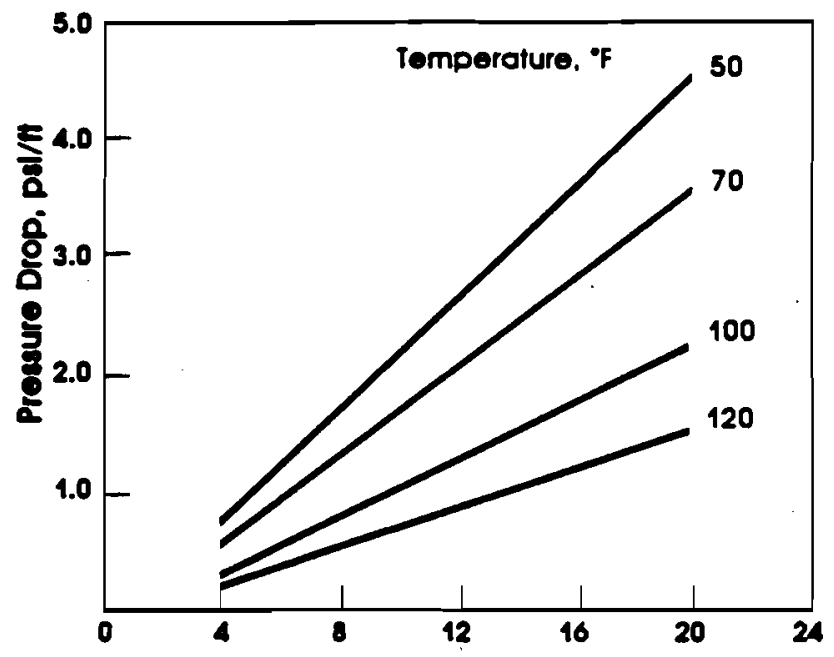

Unear Veloclty, gpm/ $\mathrm{m}^{2}$

\section{SAFE HANDLING}

Caution: Acidic and basic regenerant solutions are corrosive and should be handled in a manner that will prevent eye and skin injury.

Nitric acid and other strong oxidizing agents can cause explosive reactions when mixed with ion exchange resins. Processing equipment designed to prevent rapid buildup of pressure is necessany when an oxidizing agent such as nitric acid is utilized. Before placing strong oxidizing agents in contact with lon exchange resins, consult sources knowledgeable in the handling of these materials. 


\section{Ion Exchange Resins}

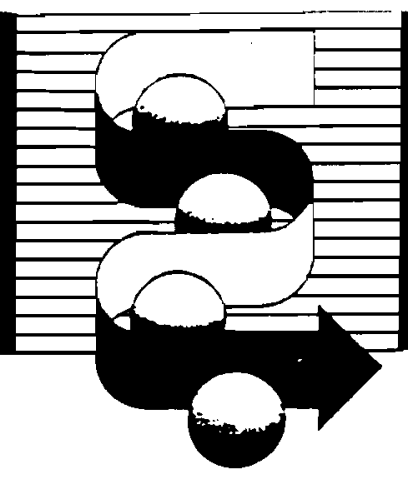

AMBERLITE ${ }^{\circ}$ IRC-50

\section{IMPORTANT NOTICE}

The fundamental dota contained in this technical bulletin may not be applicable to all field situations without some modification. An engineering company or equipment manufacturer who will give consideration to the specific conditions of operation should be consulted before any attempt is made to use these data in the design of a commercial scale operation.

\section{Introduction}

Amberlite IRC-50 is a synthetic cotion exchange resin produced in the form of white. opaque beads. Its unusually high exchange capacity is derived from carboxylic acid groups.

Supplied in the hydrogen or "free-acid" form. Amberlite IRC-50 can be converted readily to the sodium salt by treatment with a solution of sodium hydroxide. In the sodium form. the resin undergoes reactions typical of the salt of a weak acid and strong base.

Because of its selectivity for the hydrogen ion, any absorbed cation can be desorbed easily with a regeneration efficiency approaching 100 percent by treatment with dilute mineral acid.

The carboxylic functionality and exchange selectivities of Amberlite IRC-50 lead to immediate consideration of this ion exchange resin in a variety of applications such as the neutralization of strong bases: the recovery of metallic ions; the isolation and concentration of antlbiotics, basic amino acids, enzymes. and peptides.

\section{Summary}

Table 1 suggests general operating conditions for Amberlite IRC-50.

Rohm and Hoos Compony 1989
TABLE 1

Suggested Operating Conditions

\begin{tabular}{ll}
\hline pH Limitation & None \\
\hline Maximum Temperature & $212^{\circ} \mathrm{F}\left(100^{\circ} \mathrm{C}\right)$ \\
\hline Minimum Bed Depth & 24 inches \\
\hline Backwash Flow Rate & 2 to $3 \mathrm{gal} / \mathrm{ft}^{2} / \mathrm{min}$ \\
\hline Regenerant Concentration & $\begin{array}{l}1 \text { to } 5 \mathrm{percent} \mathrm{HCl} \text { or } \\
1 \text { to } 5 \mathrm{percent} \mathrm{H}_{2} \mathrm{SO}_{4}\end{array}$ \\
\hline Butfering Concentration & See Text \\
\hline Regenerant Flow Rate & 0.25 to $1.0 \mathrm{gal} / \mathrm{ft}^{3} / \mathrm{min}$ \\
\hline Regeneration Level & See Text \\
\hline Rinse Flow Rate & Same as regeneration flow \\
rate initially, then $1.5 \mathrm{gal} /$ \\
$\mathrm{ft}^{3} / \mathrm{min}$ \\
\hline Rinse Water Requirements & 25 to $50 \mathrm{gal} / \mathrm{ft}^{3}$ \\
\hline Service Flow Rate & 1 to 2 gal $/ \mathrm{ft}^{3} / \mathrm{min}$ \\
\hline Exchange Capacity & See Text \\
\hline
\end{tabular}

\section{Physical and Chemical Characteristics}

Amberite IRC-50 is fumished in the form of white, opaque spherical particles. It is shipped in the hydrogen $(\mathrm{H}+$ ) form (free acid) in a wet. swollen condition.

Density (hydrogen form, as shipped): Approximately 43 pounds per cubic foot in place (backwashed and drained bed volume).

Swelling: Maximum of 100 percent upon complete conversion from hydrogen form to sodium form.

Screen Grading (wet): 16 to 50 mesh (U.S. Standard Screens)

Effectlve Size: 0.33 to 0.50 millimeters

Molsture Content: 43 to 53 percent

Uniformity Coefflelent: 2.0 maximum 
Total Exchange Capacity:

(a) Volumetric . . .3.5 meq/ml, minimum

(b) Weight . . 10.0 meq/g dry, minimum

\section{Physical Stability}

1. Swelling: Amberlite IRC-50 swells approximately 40 percent on transformation from the hydrogen to the calcium and magnesium form as shown in Table 2. This swelling is reversible and does not cause any apparent damage to the bead structure. When the exchanger is converted from the hydrogen to the sodium form, particle swelling varies linearly with increasing $\mathrm{pH}$; at a $\mathrm{pH}$ of about 10. the resin expansion reaches a maximum of 100 percent.

2. Effect of Temperature: Exchange rate and equilibria of Amberlite IRC-50 are more affected by temperatures than are the physical characteristics of the resin. The rate of exchange and the offinity for hydrogen $(\mathrm{H}+$ ) increase as operating temperatures are elevated.

3. Attrition: Extended field experience has shown that Amberlite IRC-50 has excellent ottrition resistance.

\section{Chemical Stabllity}

Amberlite IRC-50 is stable in the presence of strong alkalies and acids, aliphatic and aromatic solvents. On prolonged contact with certain organic solvents, the resin swells to some extent, but no disintegration of the exchanger beads has been observed.

\section{Operational Characteristics}

\section{Pressure Drop}

The opproximate drop in pressure to be expected for each foot of bed depth of Amberlite IRC-50 in normal downflow operation at various flow rates and temperatures is indicated by the data in Table 3.

\section{Hydraulic Expansion}

To insure proper cleaning and hydraulic classification of Amberlite IRC-50 after each operational cycle, the bed of resin should be backwashed with water for about ten minutes at a flow rate sufficient to effect a minimum of 50 percent expansion in bed volume.

The hydraulic expansion of the bed during backwashing operations is reported as a function of the flow rote at various temperatures in Table 4. Values for the calcium and sodium forms are used in the table.

\section{TABLE 2}

Percentage Swelling of AMBERLITE IRC-50 as a Function of Defense of Conversion from Hydrogen Form

\begin{tabular}{ccc}
\hline $\begin{array}{c}\text { Percent } \\
\text { Converted }\end{array}$ & Sodium & $\begin{array}{c}\text { Colcium and } \\
\text { Magnesium }\end{array}$ \\
\hline 0 & 0 & 0 \\
\hline 25 & 25 & 10 \\
\hline 50 & 50 & 20 \\
\hline 75 & 75 & 30 \\
\hline 100 & 100 & 40 \\
\hline
\end{tabular}

TABLE 3

Pressure Drop of AMBERLTE IRC-50 Beds as a Function of Flow Rate

(Calcium Form - Effective Size - $0.4 \mathrm{~mm}$, Uniformity Coefficient - 1.6) Pressure Drop. Ibs/in $2 / \mathrm{ft}$ of Bed Depth

\begin{tabular}{ccccc}
\hline Flow, $\mathrm{gPm} / \mathrm{t}^{2}$ & $35^{\circ} \mathrm{F}$ & $4^{\circ} \mathrm{F}$ & $5^{\circ} \mathrm{F}$ & $75^{\circ} \mathrm{F}$ \\
\hline 2 & 0.30 & 0.25 & 0.22 & 0.16 \\
\hline 4 & 0.66 & 0.55 & 0.48 & 0.35 \\
\hline 6 & 1.02 & 0.85 & 0.74 & 0.55 \\
\hline 10 & 1.74 & 1.45 & 1.27 & 0.93 \\
\hline 15 & 2.70 & 2.25 & 1.96 & 1.45 \\
\hline 20 & 3.60 & 3.00 & 2.62 & 1.93 \\
\hline 30 & 6.00 & 5.00 & 4.40 & 3.21 \\
\hline
\end{tabular}




\section{Swelling}

Amberlite IRC-50 has swelling properties similar to those of all weakly acidic and weakly basic ion exchange materials. In the hydrogen form. the exchanger is at its smallest volume. When completely converted to the sodium form, the exchanger will have swollen to approximately double its volume in the hydrogen form. The calcium and magnesium forms are approximately 40 percent larger than the original hydrogen form.

The amount of swelling as a function of degree of conversion is given in Table 4. Values are based on a capacity of 3.5 milliequivalents per millliter for the sodium form and 2.1 milliequivalents per milliliter for the colcium and magnesium forms. The value of 3.5 milliequivalents per millliter for conversion to the sodium form is of interest only for cases where sodium hydroxide is being removed. This will apply usually only to special coses, for example, in polishing units where conversion to the sodium form will be quite high. The capacity value of 2.1 milliequivalents per milliliter for the calcium and magnesium forms was selected as an average value to be used for the exchange of calcium and magnesium salts from their bicarbonate salts.

\section{Titration Characteristics}

The potentialities of Amberlte IRC-50 in ion exchange processes can be determined conveniently by comparing it with one of the well-known sulfonic-acid type cotion exchangers, Amberlite $\mathbb{R}-120$. The following equations. illustroting the reaction of each resin with sodium chloride and sodium bicarbanote, point to the fundamental differences in "reactivity" of the two exchangers:

Amberlite $\mathbb{R}-120$

1. $\mathrm{R2}-\mathrm{SO}_{3} \mathrm{H}+\mathrm{NaCl} \rightleftharpoons \mathrm{R}_{2} \mathrm{SO}_{3} \mathrm{NO}+\mathrm{HCl}$

2. $\mathrm{Rz}-\mathrm{SO}_{3} \mathrm{H}+\mathrm{NaHCO}_{3} \rightleftharpoons \mathrm{RZSO}_{3} \mathrm{Na}+\mathrm{CO}_{2}+\mathrm{H}_{2} \mathrm{O}$

Amberlite IRC-50

3. $\mathrm{Rz}-\mathrm{COOH}+\mathrm{NaCl} \rightleftharpoons \mathrm{Rz}-\mathrm{COONa}+\mathrm{HCl}$

4. $\mathrm{Rz}-\mathrm{COOH}+\mathrm{NaHCO}_{3} \rightleftharpoons \mathrm{R2}-\mathrm{COONa}+\mathrm{CO}_{2}+\mathrm{H}_{2} \mathrm{O}$

These reactions clearty illustrote that Amberlite IR-120 and Amberlite IRC-50 differ fundomentally in their relative affinitles for the hydrogen ion. Amberlite $\mathbb{R}-120$, containing strongly ocidic sulfonic-acid groups, is highly ionized and shows little affinity for hydrogen ion. In contrast, Amberlite IRC-50, containing slightly ionized carboxylic acid groups, shows tremendous affinity for hydrogen ions. As shown by

\section{TABLE 4}

Hydraulic Expansion of AMBERLITE IRC-50 (Co or Na) as a Function of Backwash Flow Rate-Percent Expansion

\begin{tabular}{ccccccc}
\hline & \multicolumn{2}{c}{$35^{\circ} \mathrm{F}$} & \multicolumn{2}{c}{$45^{\circ} \mathrm{F}$} & \multicolumn{2}{c}{$75^{\circ} \mathrm{F}$} \\
\cline { 2 - 8 } Flow, gpm/ $\mathbf{H}^{2}$ & A & B & A & B & A & B \\
\hline 1 & 11 & 5 & 8 & 0 & 0 & 0 \\
\hline 2 & 39 & 22 & 31 & 16 & 13 & 5 \\
\hline 3 & 66 & 39 & 54 & 31 & 28 & 1 \\
\hline 4 & 93 & 57 & 77 & 46 & 44 & 24 \\
\hline 5 & 121 & 74 & 101 & 61 & 59 & 34 \\
\hline 6 & 148 & 91 & 125 & 77 & 75 & 44 \\
\hline A.
\end{tabular}

A. Effective size $0.36 \mathrm{~mm}$. Uniformity Coefficient-1.56

B. Effective size $0.44 \mathrm{~mm}$. Uniformity Coefficient-1.65

Figure 1. IITRATON CURVES OF AMBERLIE IRC-50

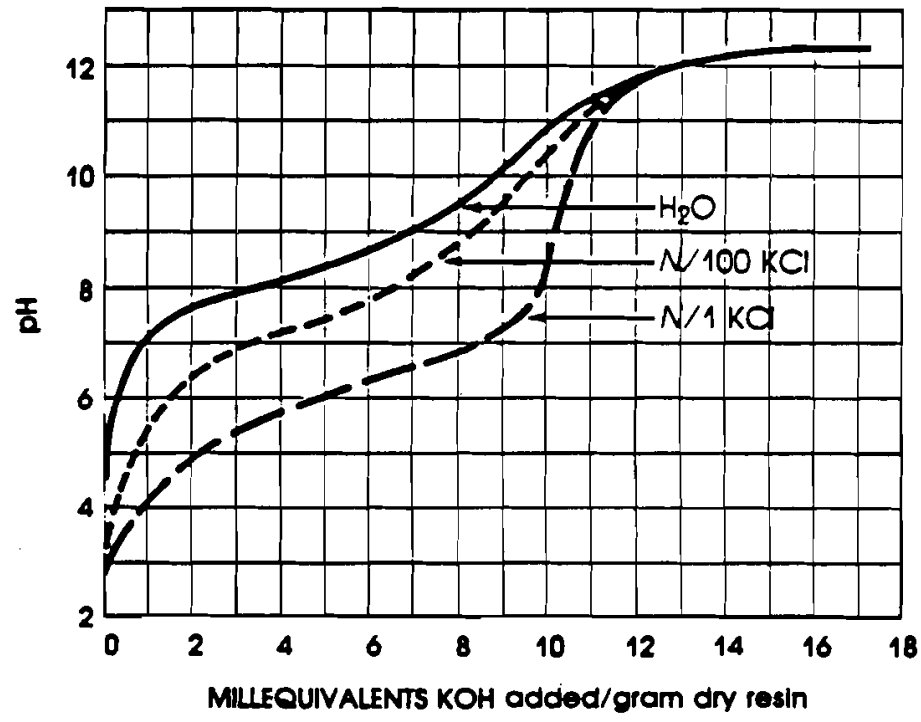


equation (1). sodium easily displaces the hydrogen in Amberlite $\mathbb{R}$ - 120 with the resulting formation of hydrochloric acid. As shown by equation (3), sodium displaces with great difficulty the hydrogen in Amberlite IRC-50 since hydrochloric acid, a strong acid, is one of the reaction products. Thus, the equillorium is shifted far to the left. As shown in equations (2) and (4), both Amberlite IRC-50 and Amberlite IR-120 react easily with the salt of a weak acid. In these reactions. Amberlite IRC-50 is active because few free hydrogen ions result from the exchange.

The hydrogen ions of both exchangers can be removed readily by simple neutralization with alkalies as shown in the following reaction between the carboxylic-acid exchanger and sodium hydroxide:

$$
\mathrm{Rz}-\mathrm{COOH}+\mathrm{NOOH} \rightleftharpoons \mathrm{Rz}-\mathrm{COONO}+\mathrm{H}_{2} \mathrm{O}
$$

Here, Amberlite IRC-50 functions because only a low concentration of free hydrogen ion is formed during the neutralization reaction.

The product obtained on neutralization of Amberlite IRC-50 is the salt of a weak acid; and some hydrolysis will occur, therefore, as the salt form remains in contact with water. The extent of this reaction will depend upon the valence of the cation involved. Whereas the hydrolysis of the resin salts of polyvalent (di-, tri-, etc.) cations is negligible, the hydrolysis of the alkali metal derivatives of Amberlite IRC-50 occurs to a slight, but measurable, degree.

The relative affinity of Amberlite IRC-50 for various cations has been checked carefully. With the exception of hydrogen. the exchange potentials of all metal ions are in the same range for both carboxylic and sulfonic exchangers. Exchange potential series for Amberlite IRC-50 and Amberlite IR-120 are shown for comparison:

Amberlite IRC-50

$$
\begin{gathered}
\mathrm{H}+>\mathrm{CA}++>\mathrm{Mo}++>\mathrm{Na}+ \\
\text { Amberlite } \mathbb{R}-120^{\circ} \\
\mathrm{Fe}+++>\mathrm{Al}+++>\mathrm{Co}++>\mathrm{MO}++>\mathrm{Na}+>\mathrm{H}+
\end{gathered}
$$

OEach series represents decreasing exchange potentiols. reoding from left to right.

\section{Exchange Capacity}

The total exchange capacity of Amberlite IRC-50 is attainable only at high pH values. In strongly alkaline media. it is possible to utilize all of the carboxylic acid groups calculated to be present in the resin matrix. Amberlite
IRC-50 exhibits a minimum weight capacity of 10.0 milliequivalents per ary gram, and a volume capacity of approximately 3.5 milliequivalents per milliliter, when all capacity measurements are based on the density of the hydrogen form of the exchanger.

Since Amberlite IRC-50 possesses great affinity for hydrogen ions, the exchange capacity will be affected considerably by the $\mathrm{pH}$ of the solution being treated. Above the neutral point ( $\mathrm{pH} 7.0)$, almost all of the carboxylic acid groups participote in exchange reactions, while below pH 7.0, the resin rapidly reverts to the hydrogen form and shows progressively less capacity for metallic ion exchange. At a pH of about 3.5. Amberlite IRC-50 exists primarily as the free acid and does not exchange appreciably with other cotions.

At the point of neutrality ( $\mathrm{pH} 7.0$ ). Amberlite IRC-50 possesses a weight capacity that can be as high as 8.0 milliequivalents per dry gram and a volume capacity as high as 2.8 milliequivalents per milliliter, depending on the ionic strength of the solution being treated.

\section{Regeneration}

Dilute hydrochloric or sulfuric acid can be employed to regenerate Amberlite IRC-50. Concentrations from one to ten percent may be used, however, care must be observed when using sulfuric acid not to precipitate calcium sulfate. Amberlite IRC-50 can be completely regenerated by treating with an amount of acid equivalent to 110 percent of the amount of cations removed. For example, if 3.0 equivalents per liter are utilized in the cation uptake. one would use approximately 3.3 equivalents of acid per liter of Amberlite IRC-50 for regeneration. For appropriate rates of flow during regeneration, see Column evaluation section 3.

\section{Determination of Exchange Capacity}

To facilitate evaluation of Amberlite IRC-50 in various applications, standard techniques for obtaining total exchange capacity and capacity at pH 7.0 are described:

Total exchange capacity: The maximum capacity of Amberlite IRC-50 can be determined conveniently by equilibrating a representative sample in the hydrogen form with an excess of $0.1 \mathrm{~N}$ sodium hydroxide. The resin should remain in contact with the excess caustic for 24 to 48 hours. The amount of sodium hydroxide neutralized is considered 
equivalent to the moximum capacity of the exchanger.

Capacity at pH 7.0: The maximum capacity available at $\mathrm{pH} 7.0$ is determined by first saturating Amberlite IRC-50 with a normal solution of sodium chloride which is $0.1 \mathrm{~N}$ with respect to sodium hydroxide. The exchanger is next rinsed with a pH 7.0 buffer (sodium acetate-ocetic acid) until the rinsings maintain a constant pH of 7.0. After the sample has been washed several times with distlled or deionized woter, it is placed in an excess of $0.1 \mathrm{~N}$ hydrochloric acid. The decrease in amount of acid is considered equivalent to the exchange capacity at pH 7.0.

\section{Column Evaluations}

When Amberlite IRC-50 is employed in column studies, several precautions should be observed.

1. It should be recalled that the exchanger swells approximately 100 percent on conversion from the hydrogen to the sodium form. In small tube evaluations, extreme care is necessary to prevent column packing, bed channeling. or improper hydraulic classification resulting from this volume change. A twoinch column instead of the standard on $\theta$-inch tube is recommended for laboratory work.

2. Exhaustion flow rates must be adjusted to the resin form. If Amberlite IRC-50 is being employed in the free acid $(H+)$ form for adsorption, the exchange rate is slow and a very low rate of flow is advisable $(0.134$ milliliters per minute per milliliter of resin). On the contrary. if the sodium salt of Amberlite IRC-50 is used for the adsorption cycle, rapid exchange occurs, and a much higher flow rate $(0.268$ milliliters per minute per milliliter) can be employed.

3. The exchanger form also determines regeneration flow rates. If it is desired to convert Amberlite IRC-50 from the free acid $(\mathrm{H}+)$ to a salt by regeneration with sodium hydroxide, potassium hydroxide, ammonium hydroxide, etc., a flow rate up to $(0.670$ millliters per minute per milliliter of resin) can be employed. To regenerate an exhousted salt form of the exchanger with acid, fiow rates of 0.134 milliliters per minute per milliliter should be used.

\section{Applications}

The foregoing sections of this bulletin, describing the fundamental characteristics of
Amberlite IRC-50. have shown that the usefulness of this resin in exchange processes stems from the exchange selectivity of the carboxylic acid groups. These functional groups impart three basic properties to Amberlite IRC-50, all of which depend upon the exchanger's affinity for the hydrogen ion.

Non-reactlvity toward neutral salts: Since Amberlite IRC-50 shows only slight activity below $\mathrm{pH}$ 3.5. neutral salts can not be split effectively. This point was illustrated in an earlier section of this bulletin (see Titration Characteristics).

Buffering capaclty: Amberlite IRC-50 can be buffered easily because of its weak-acid characteristics. Almost any ratio of salt to free acid $(H+)$ groups can be obtained by treating the resin with appropriate buffer systems. Thus, adsorption can be pertormed at controlled $\mathrm{pH}$ volues-operations almost impossible to achieve with a strong-acid type cation exchanger such as Amberlite IR-120.

Acld regeneration efficlency: Because of the affinity of Amberlite IRC-50 for hydrogen ion, dilute acids can be employed to regenerate the exchanger with efficiencies approaching 100 percent. Previously, where sulfonic-acid type exchangers have been applied to certain processes, the adsorbed ions are held so strongly that very large volumes of acid are required to recover the desired materials from the resin. In foct. the efficiency of acid $(\mathrm{H}-)$ as a regenerant for sulfonate exchangers is so low that many ion exchanger applications have been found impractical for large-scale operations. Amberlte IRC-50 eliminates these difficulties.

\section{Organic Compounds}

The butfering capacity and acid-elution efficiency of Amberlite IRC-50 have been demonstrated by applying the exchanger to the absorption and recovery of several classes of organic compounds. The compounds investigated included the following: basic amino acids (arginine, histidine and lysine): alkaloids (nicotine and quinine): vitamins (thiamine); and miscellaneous bases such as adenine, pyridine, hydrazine and ommonia.

Basic amino acld separations wilth Amberilte IRC-50: Considerable information has been collected by investigators on the use of a synthetic sulfonic-acid type cation exchanger to concentrate and separate the basic 
amino acids (arginine, histidine and lysine) from a protein hydrolysate. Present processes involve treating a protein hydrolysate with the hydrogen form of a sulfonic exchanger. The arginine, histidine and lysine are adsorbed preferentially, because their basicity is greater than that of the neutral and acidic amino acids. But difficulties are experienced in eluting the adsorbed amino acids from the exchanger. The resin-basic amino acid combination is so stable that large volumes of acid or base are required for desorption. The ultimate necessity for separating the eluting reagent from the desorbed amino acids poses a serious problem, and because of these elution difficulties, the development ion exchange process has been restricted.

With Amberlte IRC-50, the difficulties in the ion exchange process for basic amino acid separation can be eliminated. Treatment of the carboxylic acid exchanger with an appropriate buffer (sodium acetate-acetic acid) converts the resin to a combined salt-acid form so that cation exchange occurs at a controlled pH. If the ratio of sodium (salt form) to hydrogen (fre-acid form) in the exchanger is odjusted to give pH below the isoelectric points of arginine, histidine and lysine, but above the isoelectric points of the neutral and acidic amino acids, only the basic amino will exist as cations in solution and will be adsorbed by Amberlite IRC-50, while the other amino acids will pass through the resin bed unaffected.

The results in Table 5, were obtained using the column technique and an exhaustion flow rote of 0.268 milliliters per minute per milliliter of resin. The effluent characteristics were ascertained with a ninhydrin spot test, sensitive to a microgram of amino acid per milliliter of solution. The influent amino acid concentrations were approximately 1 milligram per milliliter of solution. In preparing the resin column for adsorption of the amino acids, a butfer consisting of a mixture of $1 \mathrm{~N}$ sodium acetate and acetic acid was employed. The treatment involved first putting the resin in the sodium form by treatment with sodium hydroxide and then passing the buffer (three volumes per volume of resin) through the exchanger at a low rate of flow. The last portion of the buffer was allowed to remain in contact with the resin bed for fifteen minutes. The exchanger column was rinsed free from residual butfer with deionized or distilled water.

The results indicate that resin pre-treatment with a pH 4.70 buffer is necessary for the adsorption of all of the basic amino acids. Only lysine and arginine are adsorbed by Amberlite IRC-50 when the exchanger is treated with a pH 7.0 buffer. This leads to a method for separating histidine from arginine and lysine.

A remarkable feature of Amberlite IRC-50 in the process is the small volume of dilute acid required for complete elution of the adsorbed amino acids. Two milliequivalents of $0.1 N$ hydrochloric acid per milliliter of resin effect complete displacement of the arginine, histidine, and lysine. In contrast, over thitty volumes of $6 \mathrm{~N}$ hydrochloric acid per unit volume of resin are required to remove the basic amino acids from sulfonic-acid type cation exchangers. Moreover, a certain fraction of the basic amino acids appears to be held very tenaciously by the sulfonic resins and recycling of the acid elutrient is necessary to effect complete recovery of the adsorbed material. Only one elution is necessary with Amberlite IRC-50.

Recovery of miscellaneous substances with Amberlite 1RC-50: The unique properties of Amberlte IRC-50 have been exploited further by determining the adsorption-elution characteristics of the resin in the recovery of many ionic substances, including quinine, nicotine. thiamine, adenine, pyridine, hydrazine, ammonia, and sodium hydroxide. Both the hydrogen and sodium forms were studied in aqueous and alcohol solutions. The results of these investigations are reported in Table 6.

These results bear out the selective function of the carboxylic acid group in exchange reactions. The choice of the sodium (salt form) or hydrogen (free acid form) derivative of Amberlite IRC-50 for the adsorption cycle will vary with the nature of the substance to be recovered. If the compounds selected for study are in the salt form, the sodium derivative of the exchanger should be used. whereas the hydrogen form of the resin should be employed in the isolation of compounds in the "free base" form, especially where the materials to be adsorbed are weak bases.

If Amberlite IRC-50 is used os the hydrogen derivatlve, the acidity generated during the exchange reaction must be removed in some manner before the resin will exhibit appreciable adsorption capacity. Thus, if a "free base" is being adsorbed, exchange occurs because the displaced hydrogen ion from the exchanger combines with the hy- 
TABLE 5

Basic Amino Acid Adsorption on AMBERLTE IRC-50

\begin{tabular}{llccc}
\hline Amino Acid & \multicolumn{1}{c}{ Column Pre-Treatment } & Leakage & \multicolumn{2}{c}{ Capacity } \\
\hline Histidine & H-resin & 25 & $\mathrm{mg} / \mathrm{ml}$ & $\mathrm{g} / \mathrm{H}^{3}$ \\
\hline Lysine & H-resin & 25 & very low \\
\hline Arginine & H-resin & 25 & very low \\
\hline Histidine & Column buffered-pH 5.75 & 25 & very low \\
\hline Histidine & Column buffered-pH 5.30 & 10 & very low \\
\hline Histidine & Column buffered-pH 5.0 & $5-10$ & 18 & 510 \\
\hline Histidine & Column buffered-pH 4.7 & $2-10$ & 35 & 980 \\
\hline Lysine & Column buffered-pH 7.0 & $0-3$ & 120 & 3400 \\
\hline Lysine & No-resin & Co-100 & very low \\
\hline Arginine & Column buffered-pH 7.0 & $0-2$ & 150 & 4248 \\
\hline Arginine & No-resin & 30 & - & - \\
\hline Leucine & pH 4.70 buffer & 100 & nil & nil \\
\hline Glutamic Acid & pH 4.70 buffer & 100 & nil & nil \\
\hline
\end{tabular}

TABLE 6

Recovery of Miscellaneous Substances with AMBERLTTE IRC-50

\begin{tabular}{lccccr}
\hline Substance Recovered & $\begin{array}{c}\text { Form of } \\
\text { AMBERLIE IRC-50 }\end{array}$ & Solvent & Leakage & \multicolumn{2}{c}{ Capacity } \\
\hline Quinine sulfate & $\mathrm{Na}$ & $\mathrm{H}_{2} \mathrm{O}$ & 2 & 1.320 & 37,400 \\
\hline Nicotine & $\mathrm{Na}$ & $\mathrm{H}_{2} \mathrm{O}$ & 100 & - & - \\
\hline Nicotine & $\mathrm{H}$ & $\mathrm{H}_{2} \mathrm{O}$ & $0-2$ & 385 & 10,950 \\
\hline Thiamine hydrochloride & $\mathrm{Na}$ & $\mathrm{H}_{2} \mathrm{O}$ & $5-8$ & 53.5 & 1.510 \\
\hline Thiamine hydrochioride & $\mathrm{Na}$ & $\mathrm{C}_{2} \mathrm{H}_{5} \mathrm{OH}$ & 25 & - & - \\
\hline Adenine sulfate & $\mathrm{Na}$ & $\mathrm{H}_{2} \mathrm{O}$ & 100 & - & - \\
\hline Adenine & $\mathrm{H}$ & $\mathrm{H}_{2} \mathrm{O}$ & 100 & - & - \\
\hline Pyridine & $\mathrm{H}$ & $\mathrm{H}_{2} \mathrm{O}$ & 0 & 14 & 396 \\
\hline Hydrazine & $\mathrm{H}$ & $\mathrm{H}_{2} \mathrm{O}$ & $\mathrm{O}-2$ & 51.2 & 1.450 \\
\hline Ammonia & $\mathrm{H}$ & $\mathrm{H}_{2} \mathrm{O}$ & 0 & 78 & 2.210 \\
\hline Sodium hydroxide & $\mathrm{H}$ & $\mathrm{C}_{2} \mathrm{H}_{5} \mathrm{OH}$ & 0 & 13 & 369 \\
\hline
\end{tabular}


droxide ion of the "free base", as in neutralization. For very weak bases (pKB > 10). adsorption will be negligible with either the solt or acid form of Amberlite IRC-50.

Another significant feature of the Amberlite IRC-50 is the exchanger's reactivity in organic solvents. From the data reported in Table VI. it can be seen that both organic and inorganic ions are adsorbed by the resin from at cohol solutions. The abillty of Amberlite IRC-50 to swell in such solvents as water, ethanol, dioxane, ethylene glycol, acetone, and isopropanol indicates the exchanger may exhiblt appreciable copacity in all of these solvents.

Suggested uses for Amberlite IRC-50: The foregoing discussion describes the varied uses for this carboxylic-acid type cation exchanger. Amberlite IRC-50 has been shown to effect considerable improvement in certain exchange reactions previously accomplished with sulfonate resins, but this resin is designed to supplement the available cation exchangers such as Amberlite IR-120.

Amberlite IRC-50 deserves consideration in the treotment of sugar solutions, amino acids. enzymes, hormones, milk and milk by-products, alkaloids, vinuses, antibiotics. citus derivations. fermentation products, water supplies and industrial wastes. The exchanger should offer interesting possibillties in catalysis, ore dressing. pharmaceutical compounding. plant nutrition. and recovery of rare metals. In every field of chemistry. Amberlite IRC-50 presents new opportunities for application of ion exchange processes.

\section{Food and Drug Uses}

When employing Amberlite $\mathbb{R C}-50$ in the processing or production of any food material which is to be consumed by human beings or animals, precautions must be taken to avoid contamination which may result from extractables, bacterial action or introduction of extraneous poisonous moterials. For example. low molecular weight acrylic polymers may be present in fresh unconditioned resins and they may be extracted by the process stream unless removed by proper preconditioning treatment.

In one successful preconditioning treatment, the bed of Amberlite IRC-50 was subjected to at least three cycles of exhoustion and regeneration. The resin was exhousted with a 0.5 percent solution of sodium hydroxide. Following each of the three precondltioning exhoustion steps, the resin was regenerated with five percent sulfuric acid at a level of ten pounds $\mathrm{H}_{2} \mathrm{SO}_{4}$ /cubic foot of resin. Experience has shown that this treatment reduces the extractables to levels complying with F.D.A. Food Additive Regulation *173.25 (Formerly \#121.1148).

When resins are in continuous use, no further special treatment is necessary. When use is intermittent, however, resins should be stored under water in the regenerated form and in the absence of materials which would nourish bacterial growth. When resins have been so stored for extended periods of time. it may be necessary that the conditioning procedure described above be employed before retuming the Amberlite IRC-50 to sevice.

Since Amberlite IRC-50 has the capacity of adsorbing and releasing metal cations, care should be taken to avoid contacting the resins at any time with poisonous metallic salts which might subsequently be released to food or drug products. Also, regenerant chemicals should be chosen so as not to contain trace quantities of poisonous metal salts.

\footnotetext{
AMBERLITE is a trademark of Rohm and Haas Company, or of its subsidiaries or atfiliates. The Company's policy is to register its trademarks where products designated thereby are marketed by the Company, its subsidiaries or affiliates. These suggestions and data are based on information we believe to be reliable. They are offered in good faith, but without guarantee, as conditions and methods of use of our products are beyond our control. We recommend that the prospective user determine the suitability of our materiats and sugoestions before adopting them on a commercial scale. Sugoestions for uses of our products or the inclusion of descriptive materiol from patents and the citotion of specific patents in this publication should not be understood os recommending the use of our products in violation of any patent or as permission or license to use any patents of the Rohm and Hoas Company.
} 
615!DEER ROAD • CHERRY HILL, NJ $08034 \bullet(609)$ 354-1152

TELEX: 6503023149 - FAX: (609) 354-6165

ResinTech SIR-300 is a macroporous cation exchange resin based on the Iminodiacetate acid functional group which has chelating properties for heavy metal lons even against high concentrations of Calcium; tt is intended for use in polishing heavy metal lons from near neutral industrial wastes and process streams, and recovery of

precious metals. ResinTech SIR-300 is supplied in the sodium form as moist, tough, uniform spherical beads.

\section{FEATURES \& BENEFITS}

- ABLE TO ChELATE hEAYY METAL IONS EVEN AGAINST high CALCIUM CONCENTRATIONS - This gives high capacity for removing traces of heavy metals from waste waters that have been treated by conventional hydroxide precipitation.

- ABLe to ChELATE heAVy metals IN THE PRESENCe of COMPLEXING AGENTS - Luke complexing amines and carboxylic acids, including organic acids such as citsic, tartaric, oxalic, and gluconic, phosphates etc.

- UNIFORM PARTICLE SIZE - $98 \%$ of all beads are in the minus 16 to plus 40 mesh range; giving a LOWER PRESSURE DROP while maintaining the SUPERIOR KINETICS of standard mesh size products.

- SUPERIOR PHYSICAL STABIUTY - 95\% sphericity combined with a macroporous polymer structure, high crush strengths and uniform particle size distribution gives ResinTech SIR-300 greater resistance to bead breakage and osmotic shock. This results in longer resin life and lower pressure drop, especially in frequently regenerated systems.

\section{HYDRAULIC PROPERTIES}

PRESSURE DROP - The graph below shows the expected pressure loss per foot of bed depth as a function of flow rate, at various water temperatures.

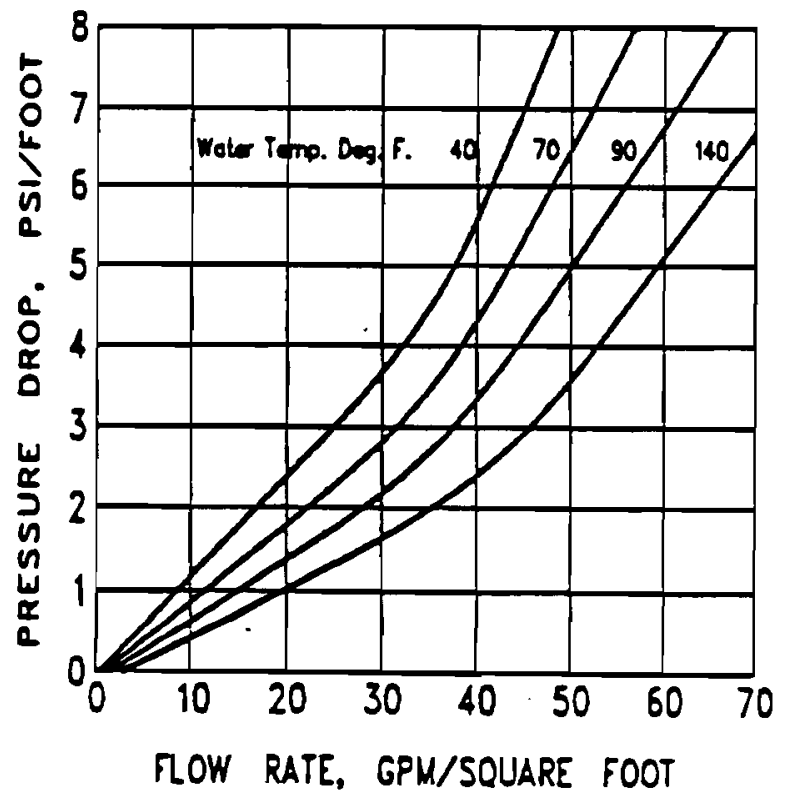

BACKWASH - After each cycle the resin bed should be backwashed at a rate that expands the bed 50 to 75 percent. This will remove any foreign matter and reciassify the bed.

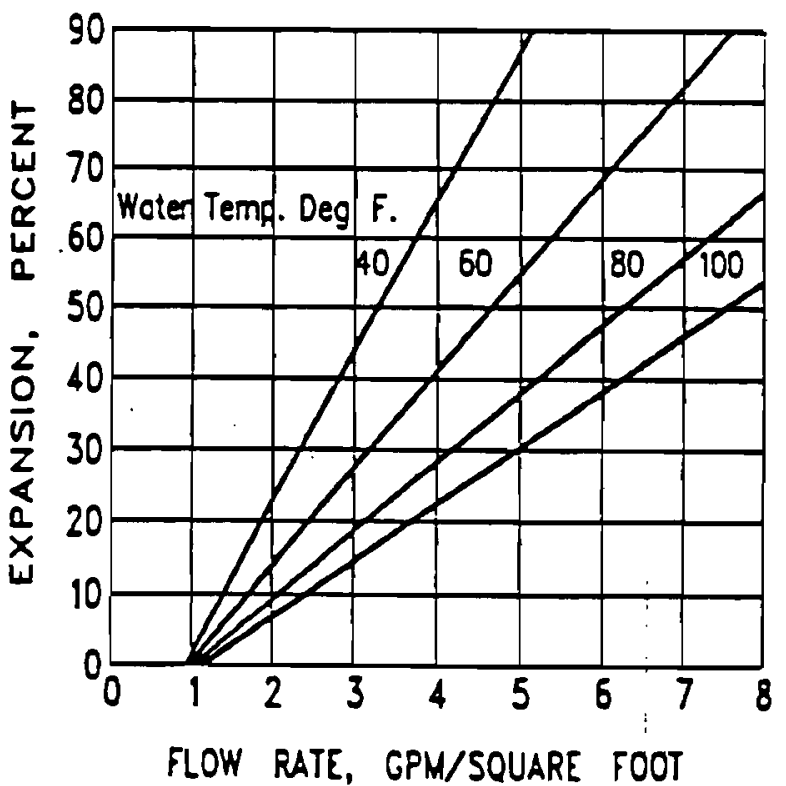




\section{TYPICAL PROPERTIES}

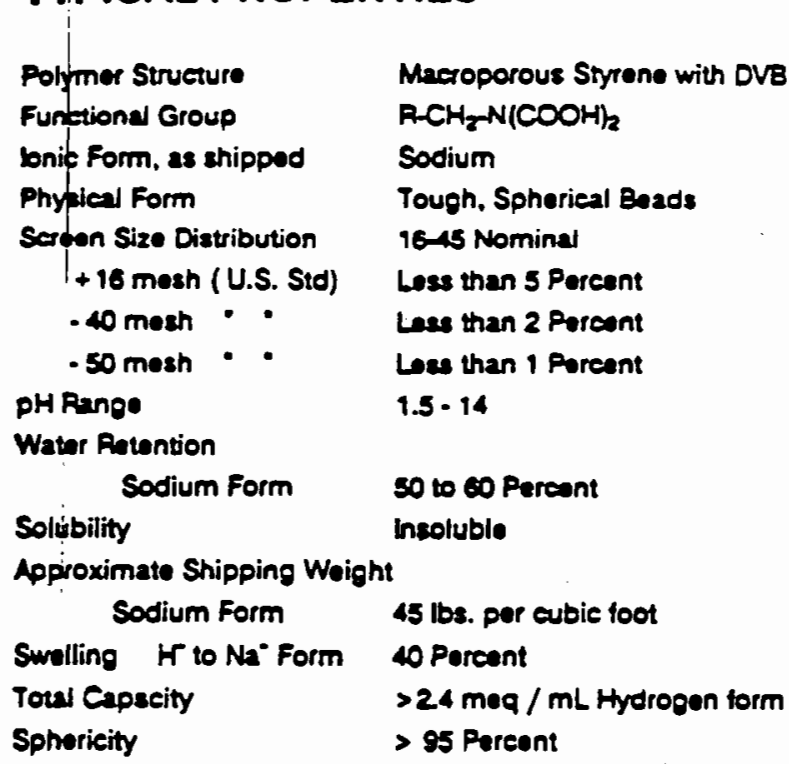

\section{SUGGESTED OPERATING CONDITIONS}

Maximum Temperature

Salt form .

Hydrogen torm

Maximum Free Chlorine

Minimum Bad Depth

Backwash Rate

Acid Ragenarant Conc."

Rogenerant Fow Rate

Regenorant Contact Time

Regoneramt Lovel

$/ \pi^{3}$

Displacamemt Finse Rate

Displacement Rinse Volume

Faxt Rinse Rate

Fast Pinse Volume

$50^{\circ} \mathrm{C}$

$60^{\circ} \mathrm{C}$

NONE

36 inches

50 to $75 \%$ Bad Expansion

$4 \cdot 10 \%$

$0.2510 .5 \mathrm{gpm} / \mathrm{tt}^{3}$

At loant 30 Minutes

8.7 (HC), or 12.5 (6. $\mathrm{SO}_{4}$ ) pounds

Same as Ragenerant Fow Rate

101020 Gallons / $\pi^{3}$

Same as Service Flow Rate

35 to 60 gal. / $\mathrm{t}^{3}$

Caustie Neutralization Cone." 4 - 10\%

Caústic Solution Flow Rate $0.2510 .5 \mathrm{opm} / \mathrm{r}^{3}$

Cavistic Contact Time

Caustic Dose Level

At leart 30 Minutes

Displacament Pinse Rate

Displacement Pinse Volume

Fast Rines Rate

Fasi Pinse Volume

2.5 to 6.0 pounds / $t^{3}$

Same as Regenerant Flow Rate

101020 Gallons / $\pi^{3}$

Same as Sorvice Fow Rate

35 to 60 gal. / t

Sonvice fow Rate

1 to $2 \mathrm{gpm} / \mathrm{n}^{3}$

"CAUTION: DO NOT MIX ION EXchange RESINS WTTH STRONG OXDIZING AGENTS. Nitrle aeld and other strong oxidizing agenis can cause exploslve reactlons when mixed whth orgenic materials, such as lon exchange resins.

\section{OPERATING CAPACITY}

The relative affinity of ResinToch SIR-300 tor heary motals in near noutral solutions is in accordance with the following

sequence.

$\mathrm{H}^{+1}>>\mathrm{Cu}^{+2}>\mathrm{V}+2>>\left(\mathrm{UO}_{2}\right)^{+2}>\mathrm{Pb}^{+2}>\mathrm{Ni}^{+2}>\mathrm{Zn}^{+2}>$ $\mathrm{Co}^{+2}>\mathrm{Cd}^{+2}>\mathrm{Fe}^{+2}>\mathrm{Be}^{+2}>\mathrm{Mn}^{+2}>\mathrm{Mg}^{+2}$. $\mathrm{Ca}^{+2}>\mathrm{Sr}^{+2}>\mathrm{Ba}^{+2}>>\mathrm{Na}^{+1}$

High concentrations of Chlorides or Sulfates, or the presence of cheating or comploxing apents ean alter this sequence and likewise will affect the oporating eapacity. Resin Tech SIR-300 has similar cholating charecteristics to EOTA and NTA Therotore It is effoctive whon these agonts are present.

As the pH decreases so does the capacity. For each particular motal ion, there is a critieal or minimum pH bolow which ResinToch SIR-300 cannot romove significant amounts of that ion. These pH values are as follows.

$\begin{array}{ll}\text { Manganese } & 4.0 \\ \text { Iron } & 3.0 \\ \text { Zne, Cobalt } & 2.7 \\ \text { Nickel } & 2.5 \\ \text { Copper } & 1.5\end{array}$

\section{SELECTIVTY SEOUENCE IN HIGH CHLORIDE SOLUTIONS}

$\mathrm{Cu}^{+2}>\mathrm{Ni}^{+2}>\mathrm{Co}^{+2}>\mathrm{Zn}^{+2}>\mathrm{CO}^{+2}>\mathrm{Fu}^{+2}$

\section{SELECTIVIT SEOUENCE IN HIGH SULFATE SOLUTIONS}

$\mathrm{Cu}^{+2}>\mathrm{NI}^{+2}>\mathrm{Cd}^{+2}>\mathrm{Zn}^{+2}>\mathrm{CO}^{+2}>\mathrm{Fe}^{+2}$

Applleatlons Inelude Waste Treatment, Chemical Processing and Resource Recovery - ReainTech SIR.300 can be used to remow haavy motal multivalent ions from a varioty of industrial effluents like oil rofineries, plating shops, mine drainage, bantery manufecturing, cooling towers etc. Consult your Resintech tochnical representative for recommendations for spocifie applieations.

AESINTECH is a tradomark of RESINTECH INC.

Thase suggestions and data are based on intormation we believe to be reliable. They are offered in good faith. However we do not make any guarites or warramec. We caution against using thase produces in an unsale manner of in violation of any patents; turther wo assume no liability tor the consequences of any suen actions. 


\author{
Leverte TP 207 \\ Produer Infornation
}

320

Levetit IP 207 is wookdy ocjoje, mesroporous carion exchenge rasin with eheleting injnodiectere groups for the sedective extretion of neavy metal cations from veskly acjdic to weakly basie solutjons. Divalent cosions use renoved from neutralized weters in the fol. lowing order:

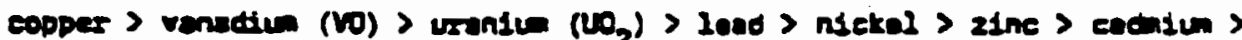

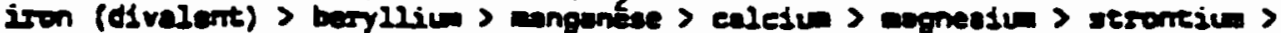
beriv $>$ sedile.

Lavats TP 207 is of seanderd bead size distgibution. Its good chemical ond mechanical seobilizy make le socially suitoble for use in ene following opdicotions:

- seleceive remoral of nuary megals eraces from effluents eftes their normel precipjestion by hydroxjdes, even in the presenes of high celciun conteres

- recorery of orecious merels from electroplaring sinse waters

- conceneretion and extraction of heovy metals from hydromesaliurgieal golueions

- recovery of precious neeals fron piekling beehs.

The selective extructson is echsered even in the presence of the

following complexing ogones:

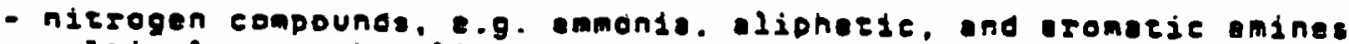

- muleivalene carborylie cejos. e.g. elesic oeid. gluconic acid. glucuronic oeid, oxolie ocid, rarraric ofid

- phosphates. e.g. terrasodium diphosphare. sodiug polyonospheze.

Levarde TP 207 does not somove heevy metals from soluzions coneaining EDTA or NTA respecejvely. Dnjy cadmiua ls romoved from coluejons containing cyansdes.

For the exerection of those heovy merols whigh foldow the urany? oxide ion in the seleetiviey. sequence se shoun bove. Lewetie Tp 207 has to be conditioned wien ceustie sode soluelon after overy ragonerceion cyelelbefore avery xhaustion cycle. After she conojeloning it is Dortieldy in cale-fora, -g. mono-sodium-form.

Before commissioning Leverte TP 207 unit, see our Toehnital Information oC/I 203430 for joboratory tests. 


\begin{tabular}{|l|c|}
\hline Ionge form, as oelivered & Nä \\
\hline Funezional groub & Iminodiacesic acid \\
\hline Masrix & Crosslinked dolystyrene \\
\hline Strueture & macrodorous \\
\hline Apdearance & Deige, odaoue \\
\hline
\end{tabular}

Physical and enemical Prodarties

\begin{tabular}{|c|c|c|c|}
\hline \multicolumn{2}{|c|}{ Bead s128" (U.S. Standart) } & min. sox mash & $16-40$ \\
\hline \multicolumn{2}{|c|}{ 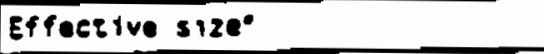 } & $\min$ & $0.55(20.05)$ \\
\hline \multicolumn{2}{|c|}{ Uniformity coefficiens" } & $\max$. & 1.7 \\
\hline \multicolumn{2}{|c|}{ Bulk velghe $(=5 x)$} & $10 s / f t^{3}$ & 50 \\
\hline \multicolumn{2}{|l|}{ Density } & aporox. g/mi & i. 18 \\
\hline \multicolumn{2}{|c|}{ water retention } & $z$ vt. & $50-55$ \\
\hline \multicolumn{2}{|c|}{ Total capaciey" (K*-fora) } & min. $09 / 6$ & 2.4 \\
\hline \multicolumn{2}{|l|}{ volum ehange } & approx. 8 & -30 \\
\hline \multirow{2}{*}{ sesoi112y } & Tempersture range & F & -1 UD TO 170 \\
\hline & DH range & & $0-14$ \\
\hline \multirow{2}{*}{ Seorab1118y } & of the Droduet & min. yesrs & 2 \\
\hline & \multicolumn{2}{|c|}{ remperazure range if } & -4 UD to 104 \\
\hline
\end{tabular}

Recemmanded Opararing condiziens"

\begin{tabular}{|c|c|c|}
\hline \multicolumn{2}{|c|}{ Oderat ing temperazure } & 176 \\
\hline \multicolumn{2}{|c|}{ Operaeing DH renge } & $1.5-9$ \\
\hline \multicolumn{2}{|c|}{ Bad depih min. it } & 3.3 \\
\hline \multicolumn{2}{|c|}{ Pressure dros ( $\left.59^{\circ} \mathrm{F}\right)$ par gom/ft" sobrox. ast/ft } & 0.12 \\
\hline Pressuro droo & max. Dsi & 36 \\
\hline \multirow[t]{2}{*}{ Fion relocity } & service & 16 \\
\hline & Dackwash(68 'F) epprox. $9 \mathrm{pm} / \mathrm{fq}^{2}$ & 4 \\
\hline Regenerant & EYDe & $\mathrm{H}_{2} \mathrm{SO}_{4}$ \\
\hline \multirow[t]{2}{*}{ Co-currene } & soprox. $1 b s / f^{3}$ & 12.5 \\
\hline & concentration & $4-10$ \\
\hline \multirow[t]{2}{*}{ Flow velociey } & regeneration approx. gorifts & 2 \\
\hline & min. $g 0 m / f q^{2}$ & 2 \\
\hline \multicolumn{2}{|c|}{ Condietoning wieh } & MaOH \\
\hline \multirow[t]{2}{*}{ Co-turrent } & level(form is shidoed) los/ft' & MONO-Na: $2.5-3$ Oi-Na: 5-6 \\
\hline & concentration & 4 \\
\hline \multirow[t]{2}{*}{ Fiou velocity } & regeneration approx. gpm/fta & 2 \\
\hline & $\min .9 \mathrm{sm} / f^{\pi}$ & 3 \\
\hline \multicolumn{2}{|c|}{ Rinse wazer reaug roment } & 37 \\
\hline Bed exoansion & Dor $90 \mathrm{~m} / \mathrm{fr}^{2}\left(68^{\prime} \mathrm{F}\right)$ & 10 \\
\hline Fraeboard & (as $z$ of resin volume) adorox. & 80 \\
\hline
\end{tabular}

Mlles Inc.

Organic Products Division - Oroanic Chemicals • Mobay Road - Pittsburgh, PA 15205-9741 - Phone: 412 777-2000

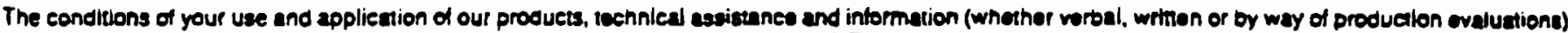

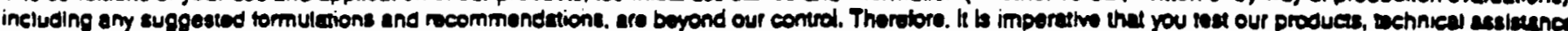

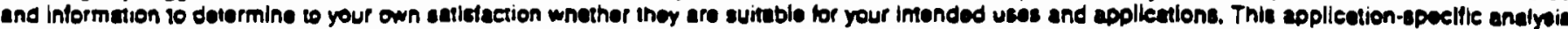

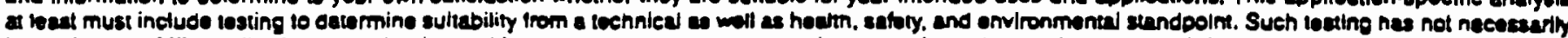

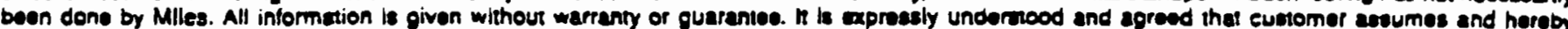

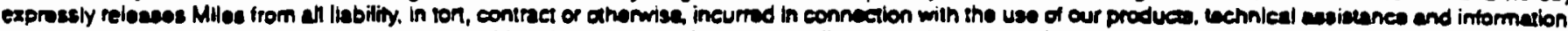

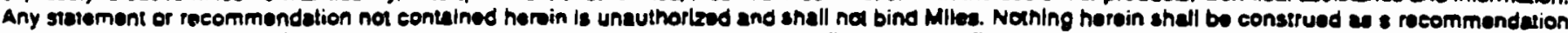

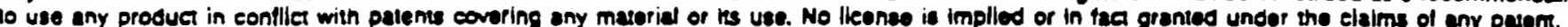




\section{TECHNICAL BULLETIN}

\section{DURASIL ${ }^{\circledR}$

Description

Application

Characteristics
DURASIL $^{\circ} 230$ media is an inorganic oxide based cation exchanger with a high specificity for radioactive cesium (Cs) and a low specificity for such nonradioactive species as sodium (Na) and lithium (L).

DURASIL 230 media was designed to selectively remove Cs radioisotopes from radwaste streams, and has been used at commercial nuclear power plants and DOE sites. It is sluiceable, bridges retention screens, and can be used in systems designed for organic resins.

DURASIL 230 media has the following characteristics:

- High capacity for Cs

- Excellent mechanical stability

- Invulnerable to attack by oxidants such as chromates and nitrates

- Non-flammable

- Does not shrink or swell

- Resists oil fouling

- Virtually immune to radiation damage and biological decay

- No effect on pH of waste stream

- Low pressure drop 


\section{Properties}

\section{Operating Performance}

Average Cs Influent Activity

$0 \quad 1.9 \mathrm{E}-03 \mu \mathrm{Ci} / \mathrm{mi}$

Average Cs Effluent Activity $\triangle \quad$ 7.7E-06 $\mu \mathrm{Ci} / \mathrm{ml}$

Average

Decontamination Factor $=247$
Base Material

Bulk Density (dry)

Maximum Swelling (\%)

Particle Size

Ion Exchange Mechanism

Functional Group

Ionic Form Shipped

Exchange Capacity

pH Range

Operating Temperature

Storage Temperature

Shipped

The selectivity of DURASIL 230 media results in high media capacity and large DFs for Cs. The graph below shows actual operating performance of DURASIL ${ }^{\circ} \mathbf{2 3 0}$ media in the treatment of a radioactive wastewater stream. The total volume radwaste processed was 2,120,100 gallons with an average conductivity of $163 \mu \mathrm{mho} / \mathrm{cm}$. Other chemistry data is presented below.

Acidic

Sodium

$32-140^{\circ} \mathrm{F}\left(0-60^{\circ} \mathrm{C}\right)$

$32-140^{\circ} \mathrm{F}\left(0-60^{\circ} \mathrm{C}\right)$

Wet

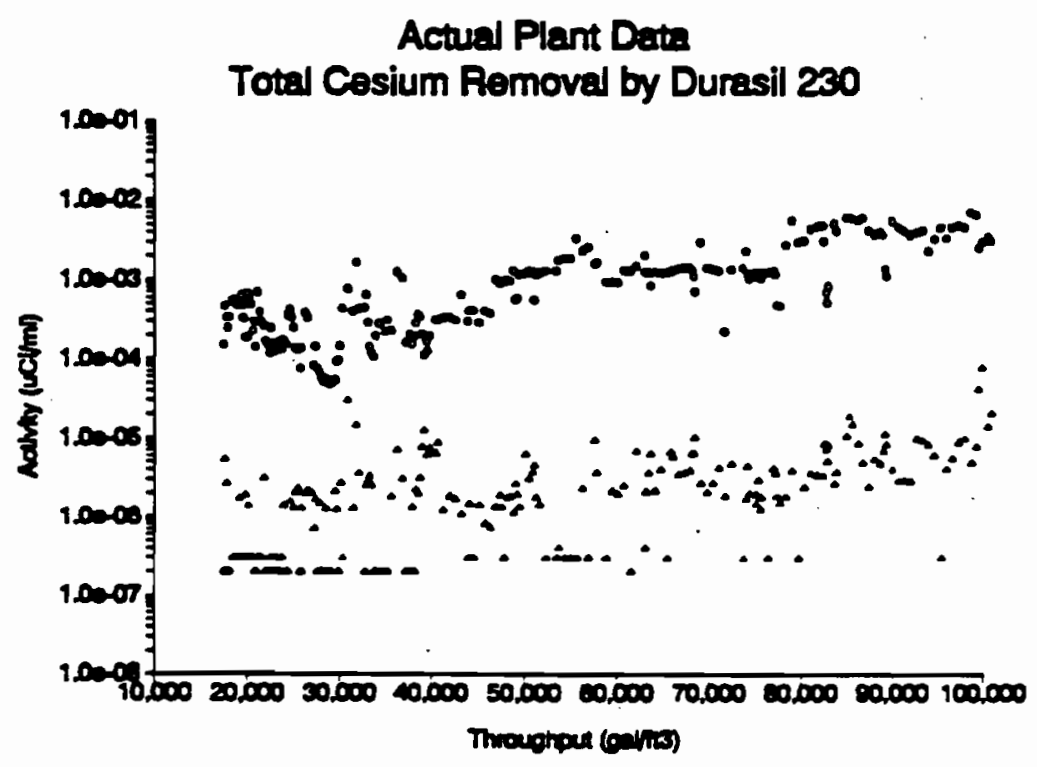

GTS DURATEK, INC. 8955 Guilford Road Suite 200

Columbia, MD 21046

(410) 312-5100

(301) 621-8211 (FAX)
GTS Duratek, Inc. reserves the right to alter characteristics of the Durasil ${ }^{\circ}$ and Dura $\mathrm{C}^{\mathrm{m}}$ media. This technical bulletin is subject to revision without notice.

DURASIL ${ }^{\circ}$ is a registered trademark of GTS Duratek, Inc. DURA $\mathrm{C}^{\mathbf{n}}$ is a trademark of GTS Duratek, Inc. 


\section{IE-95 ION EXCHANGER}

\section{Description}

UOP IE-95 Ion Exchanger is an alkali metal

alumino silicate primarily of the chabazite structure

type supplied in the mixed ionic

$(\mathrm{Na}+, \mathrm{Mg}++, \mathrm{Ca}++)$ form.

\section{Chemical Formula}

$\left(\mathrm{Na}_{2} \mathrm{O}, \mathrm{MgO}, \mathrm{CaO}\right) \cdot \mathrm{Al}_{2} \mathrm{O}_{3} \cdot 4-6 \mathrm{SiO}_{2} \cdot \mathrm{H}_{2} \mathrm{O}$

\section{Shipping Information}

IE-95 Ion Exchanger is available in $20 \times 50$ mcsh

form. Samples may be obtained on request.

\section{Regeneration}

Typically, regeneration may be accomplished by the use of $\mathrm{NaCl}$ solution of the regenerant nuid.

\begin{tabular}{ll} 
Typical Properties & \\
\hline Parieal Size & Mesh $(20 \times 50)$ \\
Pore Openings & $3.7 \times 4.2 \AA$ and $2.6 \AA$ \\
Bulk Density & $40 \mathrm{lbs} / \mathrm{cu} . \mathrm{fr}$. \\
As shipped & $640 \mathrm{~kg} / \mathrm{cu} . \mathrm{m}$. \\
& $46 \mathrm{bs} / \mathrm{cu} . \mathrm{n}$. \\
Hydrated, pascked & $740 \mathrm{~kg} / \mathrm{cu} . \mathrm{m}$. \\
BS\&D Density (hydrated) & $38 \mathrm{lbs} / \mathrm{cu} . \mathrm{m}$. \\
& $610 \mathrm{~kg} / \mathrm{cu} . \mathrm{m}$. \\
$\mathrm{H}_{2} \mathrm{O}$ Cunlenl & $1-10 \mathrm{wt} . \%$ \\
As shipped & $12-17 \mathrm{wl} . \%$ \\
Hydrated & $2.0-2.5 \mathrm{mcg} / \mathrm{gm}$ \\
Ion Exchange Capacity & (anhydrous) \\
\hline
\end{tabular}

\section{Typical Application Arees}

UOP IE-95 Ion Exchanger products have bcen found to be effective for recovery and storage of radio-nuclides and for cation cxchange from acid solutions.

\section{Additional Informetion}

Bulletins discussing additional applications of UOP.Molecular Sieves arc available. Call or write your nearest UOP Molecular Sieve Sales Office.

\section{Sales Offices}

\section{UOP}

Moleculer Skm Adsorbents

25 F. Algonquin Road

Des Plaines, IL 60017-5017

(708) 301-2000

FASTTRAN RECEION

Molecular Stew Adsortent

307 Fallewahlp Drivo

Sulte 207

Mt. Laurd. N] 08054

MIIXWESTERN ME:CION

Moloculer Slew Adeorbente

10 Soutli RIwerside Plese, Suite 2200

Chleage, IL e0008-3482

(313) 454.2230

Molecular Slew Adsorbent

25111 Counts Club blvd.

Suite 285

N. Olmated, OH 44070

(216) 734.0059
SOUTHWTSTEAN REGION

Moleculer Slewe Adeortments

13105 Northureal Frenray

Sulte mo

Hnucton, TX 77040

(713) 744-2840

BACDTCRECION

Molwollar Slow Adorbance

$123 \%$ L wis Stroet, Suite 201

Carden Grove CA 82610

(714) 750.1551

CANADA

UOP Canada, Ine.

Sulle 18c0, 444-5uh Ale, S.W.

Calgary: Alberte I2P 2TR, Canade (403) 294.1757
UOP Cenede, Ine.

190 Edintun Ave Fast

Suite 304

Toronta, Ontarla MAP IE2, Canade (di) 4 R8.4759

EURORE

UOR M.S. S.p.A.

Vin Duriui 27

2mes Mlleng ledy

30-2-76004773

UOP

Molecular Sieve Adwortents

P.O. Bas 9248. .7. 25

Dulani Interuationd Trade Contro

Dubui. United Arab F.miralex

(977-4) 313.84)
PAR EAST

UOR X.X.

Shrepore Reprowentative Office

Molecular Sieve Adsortents

101 Thomeon Rond

Il-05 Unlied Sousere

Singepore 1130

(R5) 253 -1652

UNION SHOWA $\mathrm{R} . \mathrm{K}$.

Molecular Stow Adsorbente

Senwe Butlding

27-17 Hamamatru-cha 1 Chome Minato-ku Tblyu 105. Japan (81) 3.3432.7553 
Property

Buik Density

Particle size

Ion Exchange Capacity

Pore Openings

$\mathrm{H}_{2} \mathrm{O}$ Content

Chemical Formula

\section{Typlcal Value}

55 LBS/FT3

$20 \times 50$ Mesh

$2.0-2.5 \mathrm{meg} / \mathrm{gm}$

(anhydrous)

$3.7 \times 4.2 A$ and $2.6 A$

20-25 wt?

$\left(\mathrm{Na}_{2} \mathrm{O}, \mathrm{MgO}, \mathrm{CaO}\right) \bullet \mathrm{Al}_{2} \mathrm{O}_{3} \bullet 4-6 \mathrm{SiO}_{2} \cdot \mathrm{H}_{2} \mathrm{O}$ 